\title{
19th century glacier retreat in the Alps preceded the emergence of industrial black carbon deposition on high-alpine glaciers
}

\author{
Michael Sigl $^{1,2}$, Nerilie J. Abram ${ }^{3}$, Jacopo Gabrieli ${ }^{4}$, Theo M. Jenk ${ }^{1,2}$, Dimitri Osmont ${ }^{1,2,5}$, and \\ Margit Schwikowski ${ }^{1,2,5}$ \\ ${ }^{1}$ Laboratory of Environmental Chemistry, Paul Scherrer Institut, 5232 Villigen, Switzerland \\ ${ }^{2}$ Oeschger Centre for Climate Change Research, University of Bern, 3012 Bern, Switzerland \\ ${ }^{3}$ Research School of Earth Sciences and the ARC Centre of Excellence for Climate System Science, \\ Australian National University, Canberra 2601 ACT, Australia \\ ${ }^{4}$ Institute for the Dynamics of the Environmental Sciences, National Research Council (IDPA-CNR), 30172 Venice, Italy \\ ${ }^{5}$ Department of Chemistry and Biochemistry, University of Bern, 3012 Bern, Switzerland
}

Correspondence: Michael Sigl (michael.sigl@psi.ch)

Received: 29 January 2018 - Discussion started: 20 February 2018

Revised: 17 September 2018 - Accepted: 19 September 2018 - Published: 16 October 2018

\begin{abstract}
Light absorbing aerosols in the atmosphere and cryosphere play an important role in the climate system. Their presence in ambient air and snow changes the radiative properties of these systems, thus contributing to increased atmospheric warming and snowmelt. High spatio-temporal variability of aerosol concentrations and a shortage of longterm observations contribute to large uncertainties in properly assigning the climate effects of aerosols through time.

Starting around AD 1860, many glaciers in the European Alps began to retreat from their maximum mid-19th century terminus positions, thereby visualizing the end of the Little Ice Age in Europe. Radiative forcing by increasing deposition of industrial black carbon to snow has been suggested as the main driver of the abrupt glacier retreats in the Alps. The basis for this hypothesis was model simulations using elemental carbon concentrations at low temporal resolution from two ice cores in the Alps.

Here we present sub-annually resolved concentration records of refractory black carbon (rBC; using soot photometry) as well as distinctive tracers for mineral dust, biomass burning and industrial pollution from the Colle Gnifetti ice core in the Alps from AD 1741 to 2015. These records allow precise assessment of a potential relation between the timing of observed acceleration of glacier melt in the mid-19th century with an increase of $\mathrm{rBC}$ deposition on the glacier caused by the industrialization of Western Europe. Our study reveals that in $\mathrm{AD} 1875$, the time when $\mathrm{rBC}$ ice-core con-
\end{abstract}

centrations started to significantly increase, the majority of Alpine glaciers had already experienced more than $80 \%$ of their total 19th century length reduction, casting doubt on a leading role for soot in terminating of the Little Ice Age. Attribution of glacial retreat requires expansion of the spatial network and sampling density of high alpine ice cores to balance potential biasing effects arising from transport, deposition, and snow conservation in individual ice-core records.

\section{Introduction}

The role of aerosols in climate forcing (defined as perturbation of the Earth's energy balance relative to the preindustrial) is significant but poorly understood (Charlson et al., 1992). Aerosol emissions and their atmospheric burden vary in time and from region to region; some aerosols cause cooling while even co-emitted species can lead to simultaneous warming. This results in large uncertainties of the ascribed radiative forcing terms to short-lived aerosols in contrast to greenhouse gas forcing (Bond et al., 2013; Dubovik et al., 2002).

Black carbon $(\mathrm{BC})$ has a unique and important role in the climate system because it absorbs solar radiation even at very low concentrations, influences cloud formation, and enhances the melting of snow and ice via albedo feedbacks (Flanner et al., 2007; Hansen and Nazarenko, 2004). BC is 


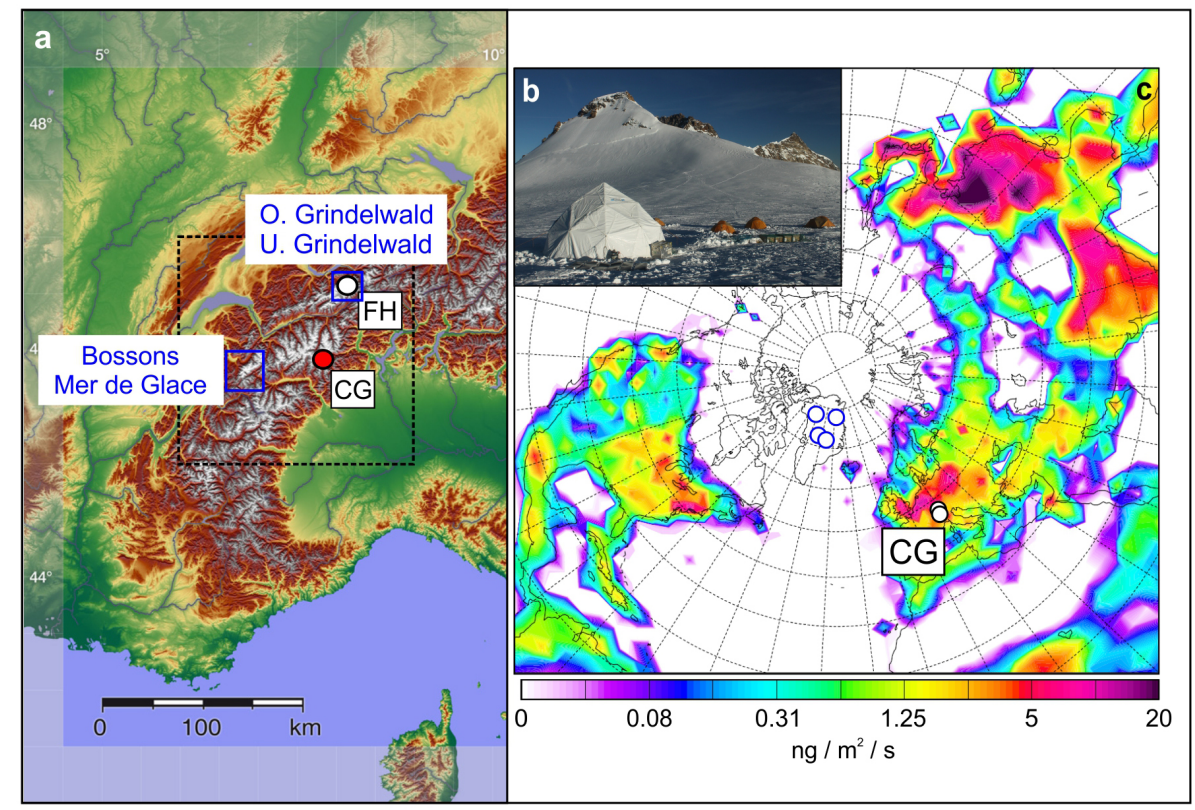

Figure 1. (a) Colle Gnifetti (CG) and Fiescherhorn (FH) ice-core drilling sites, high resolution glacier length reconstructions from the Bernese Alps (Oberer Grindelwald, Unterer Grindelwald) and French Alps (Bossons, Mer de Glace). Dashed rectangle encompasses the six $1^{\circ} \times 1^{\circ}$ grids used for the comparison of gridded black carbon (BC) emission estimates (Bond et al., 2007) with ice-core BC concentrations (Fig. 6); source: Perconte (based on SRTM-Data; CC BY-SA 2.5: https://creativecommons.org/licenses/by-sa/2.5, last access: 29 July 2016), via Wikimedia Commons. (b) Drilling site of the new CG15 ice-core at $4450 \mathrm{~m}$ a.s.l. (source: Michael Sigl); (c) Alpine and Greenland ice-core drilling sites superimposed on present-day annual mean fossil fuel and biofuel BC emission estimates (adapted from Stohl, 2006).

defined as an incomplete combustion product from natural biomass burning (e.g. forest fires) or anthropogenic biofuel and fossil-fuel burning. It is insoluble, refractory, strongly absorbs visible light, and forms aggregates of small carbon spherules. Per unit mass, BC has the highest light absorption of all abundant aerosols in the atmosphere (Bond et al., 2013). Given that carbonaceous aerosols in the atmosphere present a continuum of varying physical and chemical properties, their quantification is strongly related to the analytical method used. A wide range of terminologies has developed in the scientific community to characterize $\mathrm{BC}$ and related carbonaceous aerosols, and we follow the terminology recommendations recently put in place (Petzold et al., 2013). Refractory black carbon (rBC) will be used instead of black carbon for reporting concentrations derived from our laserbased incandescence method, while the general term black carbon (BC) is used for a qualitative description when referring to light-absorbing carbonaceous substances in atmospheric aerosol. If analysed with a thermal optical method, $\mathrm{BC}$ is also referred to as elemental carbon (EC) (Currie et al., 2002).

While natural sources such as forest fires dominated the global BC burden in the pre-industrial atmosphere, current emissions are largely driven by industrial, energy related sources (Bond et al., 2013). The modern burden is highest in heavily industrialized and populated regions including China, India, and Europe (Fig. 1). Trends in BC emissions estimated from bottom-up approaches (i.e. from fuel consumption data) suggest large changes during the industrial era (Bond et al., 2007; Lamarque et al., 2010), which were recently largely confirmed by continuous measurements of BC in Greenland ice cores (Bauer et al., 2013; Koch et al., 2011; Y. H. Lee et al., 2013; McConnell et al., 2007). However, multiple source regions contribute in varying degrees to the BC deposition over Greenland, hampering attribution of the observed trends to individual emission source areas (Hirdman et al., 2010; Liu et al., 2011).

Together with mineral dust and other absorbing organic aerosols, $\mathrm{BC}$ deposited on snow and ice can lead to increased melt rates and changes in melt onset due to reductions in surface albedo. These effects are further enhanced by subsequent snow albedo feedbacks such as an increase in the water content and surface accumulation of impurities (Flanner et al., 2009; Hansen and Nazarenko, 2004). The best estimate for industrial era global forcing of $\mathrm{BC}$ is $+0.13 \mathrm{~W} \mathrm{~m}^{-2}$, but values for regions with seasonal snow cover (e.g. the Arctic, European Alps, Tibetan Plateau) are much higher (Bond et al., 2013). Industrial BC deposition has been suggested as being responsible for observed Arctic warming in the 1940s and recent years (Flanner, 2013; Flanner et al., 2009; Quinn et al., 2008) but recent surface albedo decreases (i.e. darkening) of the Greenland ice sheet occurred in the face of a widespread decrease in BC deposition based on multiple ice cores (Keegan et al., 2014; McConnell et al., 2007), sug- 
gesting a small role for light absorbing impurities in causing these changes (Polashenski et al., 2015). In the Himalayas the combined increased deposition of mineral dust and industrial black carbon was suggested to play a role in the observed glacier retreat during the past decades (Flanner and Zender, 2005; Kaspari et al., 2011; Lau et al., 2010; W. S. Lee et al., 2013). In contrast to climate effects from direct radiative forcing (Bond and Sun, 2005; Penner et al., 1998) and cloud effects (Haywood and Boucher, 2000; Lohmann and Feichter, 2005) that are short lived and effective only during the brief atmospheric lifetime of the aerosols (from days to a week), BC-induced changes in the snow cover persist for longer periods of time ranging from weeks-to-months. They are most pronounced during the spring and summer, when insolation and seasonal snowmelt reach a maximum (Flanner et al., 2009).

To quantify trends and magnitudes of climate forcing from $\mathrm{BC}$ in the atmosphere (direct and indirect effect) and cryosphere (snow-albedo effect) climate-model simulations are widely used (Bond et al., 2013; Lamarque et al., 2013; Shindell et al., 2013). These rely strongly on energyconsumption based estimates of $\mathrm{BC}$ emissions that are highly uncertain (see Fig. 8 in Bond et al., 2007) and thus need to be evaluated against independent ice-core based observations (Bauer et al., 2013; Y. H. Lee et al., 2013). Those comparisons allow identification of mismatches and can subsequently help to improve parameterization and model performance (Lamarque et al., 2013).

Mountain glaciers are retreating worldwide and are projected to further shrink with the expected increase in global surface temperatures due to increasing greenhouse gas concentrations (Mernild et al., 2013; Oerlemans, 2005; Zemp et al., 2006). While the currently observed mass loss is global in scale and attributed to anthropogenic greenhouse gas emissions, the onset of melting during the 19th century was asynchronous for many mountain regions (e.g. between Scandinavia and the Alps; Imhof et al., 2012; Larsen et al., 2013). Observations place the start of the retreat in the Western Alps from 1860 to 1865 after glaciers reached their maximum extent around 1850-1855 (Nussbaumer and Zumbühl, 2012; Zumbühl et al., 2008). The retreat was rapid and synchronous among different documented glaciers. By 1880 , glacier tongues had retreated by several hundred metres in length (Nussbaumer and Zumbühl, 2012). Using early instrumental temperature and precipitation data, a combination of high spring temperatures and reduced autumn precipitation was suggested as the main drivers of the observed glacier retreat (Steiner et al., 2008; Zumbühl et al., 2008). In an alternative hypothesis, early industrial $\mathrm{BC}$ deposited on snow and ice of Alpine glaciers was held responsible for the rapid melting, involving a snow-albedo feedback (Painter et al., 2013). This hypothesis built on model simulations to estimate snow albedo forcing from two ice-core based reconstructions of BC (i.e. EC) from Fiescherhorn glacier (Jenk et al., 2006) and Colle Gnifetti (Thevenon et al., 2009). Starting in the
1870 s, both records show an initial 2-3-fold increase of BC concentrations rising from a mostly natural background of $9 \mathrm{ng} \mathrm{g}^{-1}$ to more than $20 \mathrm{ng} \mathrm{g}^{-1}$, before the highest values $\left(37 \mathrm{ng} \mathrm{g}^{-1}\right)$ were reached during the early 20th century.

Transient changes in external natural (e.g. volcanic eruptions) and anthropogenic climate forcing (e.g. greenhouse gases, tropospheric aerosols) occurred during the emergence of industrialization in Europe (Eyring et al., 2016; Jungclaus et al., 2017). To isolate the often complex relationships between glacier fluctuations and meteorological forcing and to identify the mechanisms responsible for glacier retreat in the second half of the 19th century requires comprehensive modelling efforts (e.g. Lüthi, 2014; Zekollari, 2017; Goosse et al., 2018). Underpinning such efforts, accurate and precise delineation of external forcing (e.g. volcanic eruptions), potential feedbacks (e.g. BC deposition on snow) and cryosphere changes (e.g. variations in glacier front positions) is critically important.

The snow-albedo feedback hypothesis formulated by Painter et al. (2013) was a first effort to attempt this but was limited predominantly by the available $\mathrm{BC}$ data at that time (Thevenon et al., 2009; Jenk et al., 2006). The available data were of relatively low time-resolution (Thevenon et al., 2009; Jenk et al., 2006), and the dating of the Colle Gnifetti ice core was at that time not based on annual-layer dating constrained by historic age markers (Jenk et al., 2009; see Fig. S1 and Table S1 in the Supplement) and thus was highly uncertain in Thevenon et al. (2009). Measurements of EC may be subject to artifacts related to losses during filtration, interferences from mineral dust, or the pyrolysis of organic compounds (see Lack et al., 2014; Lim et al., 2014, for details). Large sample size requirements $(0.2-1 \mathrm{~kg})$ for EC quantification with traditional thermal techniques, however, made it impossible to analyse replicate core sections in order to demonstrate the repeatability of the results (Thevenon et al., 2009; Jenk et al., 2006).

Here, we set out to re-evaluate the timing of industrial BC deposition in ice cores from the Alps by using a new, more accurately dated record of $\mathrm{rBC}$ at a much higher time resolution (sub-annual). In addition, we measure distinctive tracers of anthropogenic pollution (e.g. bismuth, sulfate, lead, ammonium) and compare all records with the most highly resolved history of glacier length changes of four glaciers in the Western Alps currently available (Nussbaumer and Zumbühl 2012).

\section{Data and methods}

\subsection{Ice-core drilling site}

Two $82 \mathrm{~m}$ long ice cores (CG03A, CG03B) from the European Alps, which are surrounded by highly industrialized countries (e.g. Germany, Italy, France), representing some of the main emitters of 19th to 21 st century fossil-fuel industrial 
BC (Bond et al., 2007), were drilled in 2003 a metre apart on Colle Gnifetti (Monte Rosa, 4450 m a.s.l., $45^{\circ} 55^{\prime} 55^{\prime \prime} \mathrm{N}$; $07^{\circ} 52^{\prime} 34^{\prime \prime}$ E, Jenk et al., 2009) (Fig. 1). The drill site location on a saddle minimizes effects of lateral ice flow, but leads to seasonally weighted atmospheric signals, due to preferential wind erosion of winter snow (Bohleber et al., 2013; Häberli et al., 1983; Oeschger, 1977; Schwikowski et al., 1999a). Low annual net accumulation rates $\left(0.45 \mathrm{~m}\right.$ w.e. $\left.\mathrm{yr}^{-1}\right)$ give access to an older level of ice and allow the retrieval of longterm proxy records covering most of the Holocene (Jenk et al., 2009; Konrad et al., 2013; Sigl et al., 2009). During the summer months, the drill site is frequently situated above the planetary boundary layer. However, the site clearly records the signal of natural and anthropogenic emissions from sources located at lower altitudes, as indicated by the diurnal and annual cycle of aerosol deposition resulting from convective transport monitored in situ at Colle Gnifetti and Jungfraujoch over many years by remote sensing and high-resolution aerosol measurements (Lugauer et al., 1998; Nyeki et al., 2000). The presence of these annual cycles is the basis for the dating of these ice cores by incremental layercounting reaching as far back as 1000 years (Bohleber et al., 2018). On inter-annual timescales, the summer-biased and irregular snow deposition at Colle Gnifetti contributes to the observed variability of the proxy records, with occasionally preserved winter snowfall (e.g. in $\sim A D 1890$ ) typically having low impurity concentrations (Wagenbach et al., 2012). However, these effects are minimized at a (multi-) decadal resolution, at which these proxy records reflect changes in the source strengths of the emissions and the resulting atmospheric burden of aerosols remarkably well (Engardt et al., 2017; Fagerli et al., 2007; Gabrieli et al., 2010; Schwikowski et al., 1999b). Additional firn and ice cores (CG08, CG15) were obtained from the same site in 2008 (Kirchgeorg et al., 2013) and in September 2015, respectively, to update the long-term record to the most recent past.

The Colle Gnifetti site has produced a number of impurity and pollution records, highlighting the strong impact of human activity on the atmospheric composition over Central Europe during recent decades and centuries, including records of sulfate and nitrate (Döscher et al., 1995; Schwikowski et al., 1999a), ammonium (Döscher et al., 1996), carbonaceous aerosols (Lavanchy et al., 1999; Thevenon et al., 2009), trace elements such as lead, copper, cadmium, zinc, plutonium (Barbante et al., 2004; Gabrieli and Barbante, 2014; Gabrieli et al., 2011; Schwikowski et al., 2004), and organic pollutants (Gabrieli et al., 2010; Kirchgeorg et al., 2013). Temporal variability of mineral dust, including long-range transported dust from Africa, was investigated by Bohleber et al. (2018), Gabbi et al. (2015), Gabrieli and Barbante (2014), Wagenbach and Geis (1989), and Wagenbach et al. (1996) using calcium, sulfate, iron, and barium as mineral dust proxies.

\subsection{Analytical methods}

The top $57.2 \mathrm{~m}$ of CG03B comprising 1635 discrete samples (cross section area $1.9 \times 1.9 \mathrm{~cm}$ ) were analysed at the Paul Scherrer Institut (PSI) between May and July 2015 (Table 1) achieving sub-annual resolution since the pre-industrial (i.e. AD 1741). Concentrations of $\mathrm{rBC}$ were determined with a Single Particle Soot Photometer (SP2, Droplet Measurement Technologies, Schwarz et al., 2006) and a jet (APEX-Q, Elemental Scientific Inc.) nebulizer to aerosolize the aqueous samples (Wendl et al., 2014). BC analysis was done at approximately $2 \mathrm{~cm}$ water equivalent depth resolution. Freshly cut samples stored in polypropylene vials were melted at room temperatures, sonicated for $25 \mathrm{~min}$ and measured immediately using an auto-sampler (CETAC ASX-520). Liquid sample flow rates typically varying within $\pm 10 \%$ were measured routinely to ensure constant aerosolization efficiencies. Capillaries delivering samples to the nebulizer were rinsed at least on a daily basis with $3 \%$ nitric acid for $10 \mathrm{~min}$. For external calibration we used $\mathrm{rBC}$ standard solutions (Aquadag $^{\circledR}$, Acheson Inc.; see Wendl et al., 2014, for details) freshly prepared and directly analysed at concentrations from 0.1 to $50 \mathrm{ng} \mathrm{g}^{-1}$. To demonstrate the reproducibility of the $\mathrm{rBC}$ measurements and the robustness of the method we performed 387 replication analyses using parallel ice-core sections that comprised $20 \%$ of the length of the original analyses. The upper $11.9 \mathrm{~m}$ of CG15, in total 276 samples, were similarly analysed. Following $\mathrm{rBC}$ analyses, we determined the concentrations of major ions $\left(\mathrm{Na}^{+}, \mathrm{NH}_{4}^{+}, \mathrm{K}^{+}\right.$, $\mathrm{Ca}^{2+}, \mathrm{Mg}^{2+}, \mathrm{Cl}^{-}, \mathrm{NO}_{3}^{-}, \mathrm{SO}_{4}^{2-}$ ) using ion-chromatography (850 Professional IC, Metrohm).

For the parallel ice core CG03A a wide range of additional elemental and chemical components of aerosols had been analysed using ion-chromatography (IC, Dionex) and inductively coupled plasma mass spectrometry (ICPMS, Agilent 7500), enabling ice-core dating (Jenk et al., 2009) and detailed characterization of dust and pollution aerosols (Gabrieli and Barbante, 2014). Trace element analyses were performed at University of Venice using the ICPMS in continuous flow mode, achieving an effective sampling resolution of approximately $0.5 \mathrm{~cm}$ water equivalent (Gabrieli and Barbante, 2014). Here we present measurements of trace metals (i.e. bismuth, Bi), typically emitted by coal burning and other industrial processes (McConnell and Edwards, 2008) and of chemical tracers (i.e. calcium, $\mathrm{Ca}^{2+}$ ) typically enriched in mineral dust originating predominantly from the Saharan deserts and constituting a second potential source for light-adsorbing impurities present in Alpine glacier ice.

\subsection{Ice-core dating}

The CG03B ice core was dated against the chronology of the CG03A core (Jenk et al., 2009) using the major ion records obtained for both cores to align the records. In total, 221 stratigraphic links were established between these two 
Table 1. Ice cores, parameters, and analytical methods.

\begin{tabular}{lrrll}
\hline Ice core & Time (AD) & Depth & Analyses & Instrumentation \\
\hline CG03A & $1741-1993 / 2003$ & $0-57 \mathrm{~m}$ & Trace elements (Bi, Pb)/major ions & ICPMS, IC \\
CG03B & $1741-2003$ & $0-57 \mathrm{~m}$ & Major ions, rBC & IC, SP2 \\
CG08 & $1996-2008$ & $0-10.5 \mathrm{~m}$ & Major ions & IC \\
CG15 & $2001-2015$ & $0-11.9 \mathrm{~m}$ & Major ions, rBC & IC, SP2 \\
\hline
\end{tabular}

records between $\mathrm{AD} 1741$ and 2003, which is close to the number of annual layers identified originally in CG03A. Linear interpolation was used to date the ice between the stratigraphic tie-points. Differences in the depths for common time markers are found to be less than $13 \mathrm{~cm}$ at most (Table S1). The chronology of CG03A (Fig. S1; Table S1) was originally derived by annual-layer-counting predominantly using the $\mathrm{NH}_{4}^{+}$record and constrained by absolute age markers from volcanic eruptions, nuclear weapon testing, historic Saharan dust events and ${ }^{14} \mathrm{C}$ dating of insoluble organic carbon in the deeper core sections (Jenk et al., 2009; Sigl et al., 2009; Uglietti et al., 2016). Previously identified volcanic horizons (i.e. Katmai, 1912; Tambora, 1815; Laki, 1783) were corroborated in the new $\mathrm{CG03 \textrm {B }}$ records using $\mathrm{SO}_{4}^{2-}$ concentrations together with the ratio of $\mathrm{NSO}_{4}^{2-} / \mathrm{Ca}^{2+}$. Additional volcanic signatures (e.g. in 1809) potentially relating to a large eruption of unknown origin in $\mathrm{AD} 1809$ were detected in CG03B but have not been used to further constrain the timescale. Constrained by historic events during the beginning and end of the 19th century, maximum age uncertainties are conservatively estimated to be \pm 5 years at most during the mid-19th century (Jenk et al., 2009).

\subsection{BC emission inventories}

In the absence of direct $\mathrm{BC}$ measurements during the last few centuries, gridded emission inventories from bottom-up approaches, (e.g. Bond et al., 2007; Lamarque et al., 2010) are widely used to estimate emissions and aerosol loading. These are the final products of a wide range of estimates of activity (e.g. fuel consumption) combined with emission factors (e.g. grams of BC emitted per mass of fuel burned derived from controlled burning of fuel types under laboratory conditions) and thus carry large uncertainties (Bond et al., 2013). While the general emission trends from these inventories could be confirmed through comparison to existing icecore reconstructions (Jenk et al., 2006; Junker and Liousse, 2008; Lavanchy et al., 1999), a more detailed evaluation was hampered by the relatively large error ranges inherent in both these reconstruction approaches. For this study, we deploy the BC emission estimates from fossil-fuel and biofuel burning (available at 5-year resolution) from Bond et al. (2007), for (1) the OECD countries in Europe and (2) the mean of the grid cells $45-47^{\circ} \mathrm{N}$ and $6-9^{\circ} \mathrm{E}$ (available at 10 -year resolution) that encompasses both, our ice-core study site and the locations of various glacier length reconstructions in the Western Alps (see Sect. 2.5; Fig. 1).

\subsection{High-resolution glacier length histories from Western Alps}

Glacier fluctuations in the European Alps are among the best documented worldwide, as glaciers are situated in densely populated areas. Painter et al. (2013) used five glaciers from the Western and Eastern Alps to analyse the 19th century changes of their terminus positions, with Unterer Grindelwald glacier providing the densest observation frequency during the 19th century among these glaciers. For this study, we compile four glacier length reconstructions from the Western Alps (all situated in close proximity to the ice-core site) including Mer de Glace, Oberer Grindelwald and Unterer Grindelwald glacier, and Bossons glacier (Nussbaumer and Zumbühl, 2012), the latter offering the highest observation density during the mid-to-late 19th century with annual data coverage between AD 1850 and 1899 of $78 \%$. To analyse trends in glacier length variability relative to the increase of industrial black carbon deposition at Colle Gnifetti and Fiescherhorn (Jenk et al., 2006), we filled missing terminus position data by linear interpolation and constructed a stacked glacier length curve by averaging the terminus positions of all four glaciers.

\subsection{Time-of-emergence (ToE) analyses}

To determine the timing when $\mathrm{rBC}$ concentrations exceeded their natural variability, suggesting an additional, industrial emission source, we performed a time-of-emergence (ToE) analysis on annually averaged $\mathrm{rBC}$ concentrations. The ToE is formally defined by Hawkins and Sutton (2012) as the mean time at which the signal of change emerges from the noise of natural variability. We followed the methods of Abram et al. (2016) in defining the threshold of emergence value as the earliest occurrence where the signal-to-noise ratio exceeds the value 2 (industrial $\mathrm{rBC}$ signal is distinguishable from zero at a $95 \%$ confidence level). We consider the time period AD 1741 to 1840 as the pre-industrial reference period during which human emissions of light absorbing rBC in Central Europe was minimal, restricted to occasional forest fires and residential wood burning (henceforth summarized as biomass burning $B B$ ). To discriminate large $\mathrm{rBC}$ values caused by BB within the pre-industrial period (AD 1741- 


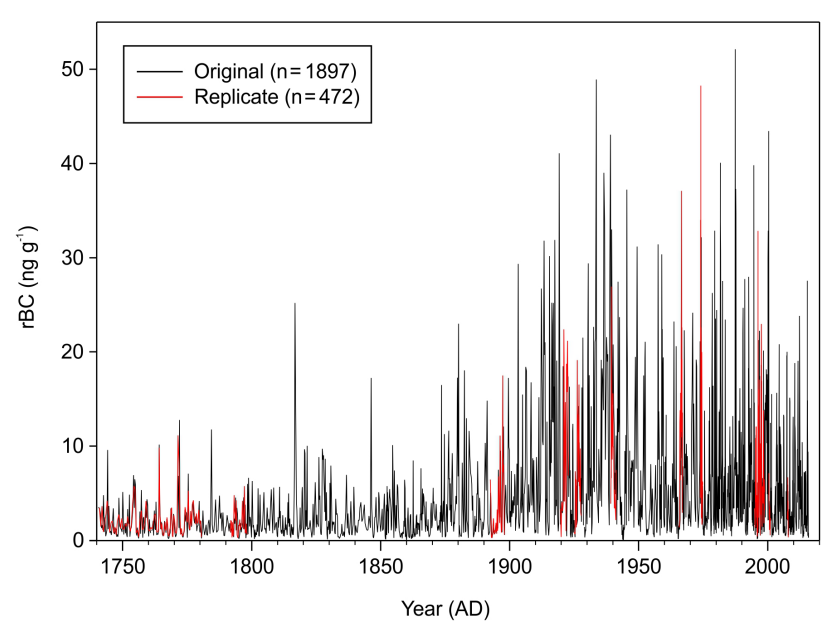

Figure 2. Combined (CG03 and CG15) Colle Gnifetti rBC concentration record including the original analysis (black) and replicate samples from parallel core sections (red) between AD 1741 and 2015.

1850) we employed a fire detection algorithm adapted from Fischer et al. (2015) and replaced the correspondent BC concentration values for detected "fire activity" years with their 11-year running medians $\left(\mathrm{BC}_{\mathrm{no}} \mathrm{BB}\right)$. The $\mathrm{ToE}$ assessment was carried out varying the length of the pre-industrial reference period and the degree of smoothing (running mean) applied to the record to determine the underlying signal. Reference periods from 15 to 100 years in length were used beginning in 1741 (i.e. shortest reference period is AD 1741-1765 and longest reference period is AD 1741-1840) were used to determine the mean and $+2 \sigma$ level of natural variability. A running mean of the same length as used for the reference period was applied to determine the signal and ToE was assigned to the year when the signal first permanently exceeded the $+2 \sigma$ value of the reference period. This method results in a distribution of ToE estimates that reflect uncertainty based on methodological choices in defining the signal and noise values used to define ToE. We assume the uncertainty in ToE to be independent from the ice-core dating uncertainty, and use their root sum square as the total uncertainty estimate of the emergence of enhanced industrial BC emissions. ToE analysis was similarly applied to total $\mathrm{rBC}$ (without discriminating $\mathrm{BB}$ years) and to $\mathrm{Ca}^{2+}$ as a proxy for Saharan dust deposition, the latter having also high abundances of light-absorbing minerals such as hematite $\mathrm{Fe}_{2} \mathrm{O}_{3}$ (Linke et al., 2006). To evaluate the sensitivity of the choice of detection method for ToE we also employed a Bayesian change-point algorithm (Ruggieri, 2013) based on a linear regression model to determine the timing for a significant change point (equivalent to the emergence) within the $\mathrm{rBC}$ time series.

\section{Results}

\section{1 $\quad B C$ and source tracer variability since AD 1741}

The synchronized records of CG03, CG08 and CG15 (Fig. S2) provide a continuous record of long-term changes of $\mathrm{rBC}$ deposition at this site from the pre-industrial (AD 1741) into the most recent past (AD 2015, Fig. 2). Deposition histories for major aerosol species are highly reproducible in the two parallel CG03 ice cores (Figs. S3, S4), indicating minimal adverse effects of snow drift and spatial variability of aerosol deposition present at these spatial scales. Measured $\mathrm{rBC}$ values at CG03B vary strongly on intra-annual timescales, with this variability being superimposed on longer-term trends. Replicate analyses performed at the end of the measurement campaign confirm that the original measurements performed over 2 months are highly reproducible over a concentration range of almost 3 orders of magnitude (Figs. 2, S5). Between 1975 and 2015 ( $N>12$ samples per year) the highest values of $>15 \mathrm{ng} \mathrm{g}^{-1}$ ( 90 percentile) are typically recorded during the summer months, reflecting increased deposition of aerosol species on the glacier during times when the planetary boundary layer reaches higher than the drilling site at $4450 \mathrm{~m}$ (Lugauer et al., 1998). During the remaining season of snow accumulation, the ice-core site is situated within the free troposphere with rBC concentrations significantly lower with approximately $0.9 \mathrm{ng} \mathrm{g}^{-1}$ (10 percentile). Due to common transport and deposition, co-variability of $\mathrm{rBC}$ with other species at intraannual resolution is indicated by significant Pearson's correlation coefficients $\left(p<0.001\right.$, one sided, $N=696, \mathrm{Na}^{+}$, $R=0.35 ; \mathrm{NH}_{4}^{+}, R=0.63$ ) for the period of the most recent 40 years.

To analyse long-term $\mathrm{rBC}$ variability we calculate annual mean values by averaging all $\mathrm{rBC}$ values within the respective calendar year (Fig. 3). Excluding occasional rBC spikes $\left(>4 \mathrm{ng} \mathrm{g}^{-1}\right.$ ) the mean $\mathrm{rBC}$ concentration in the CG03 core during the pre-industrial (i.e. AD 1741-1850) was $2 \mathrm{ng} \mathrm{g}^{-1}$, followed by a small (2-fold) increase to approximately $4 \mathrm{ng} \mathrm{g}^{-1}$ during the last two decades of the 19th century (AD 1880-1899). Maximum rBC concentrations of $10 \mathrm{ng} \mathrm{g}^{-1}$ exceeding 5 times the pre-industrial values are recorded between 1910 and 1920 and again 1933-1945, with a short decline between 1921 and $1932\left(6 \mathrm{ng} \mathrm{g}^{-1}\right)$, plausibly explained by a drop in industrial $\mathrm{rBC}$ emissions following the economic crisis between the two world wars. Since $1950, \mathrm{rBC}$ concentrations remained elevated and only started to drop significantly after AD 2000. Since then, concentrations vary around $5 \mathrm{ng} \mathrm{g}^{-1}$, still more than twice as high as during the pre-industrial period. We summarize median rBC concentrations in Table 2 together with other relevant ice-core source tracers and their main emission sources for the pre-industrial and for two periods labelled after their main fossil-fuel source as coal "COAL" (1901-1950) and petroleum products "PETROLEUM" (1951-1993), respec- 

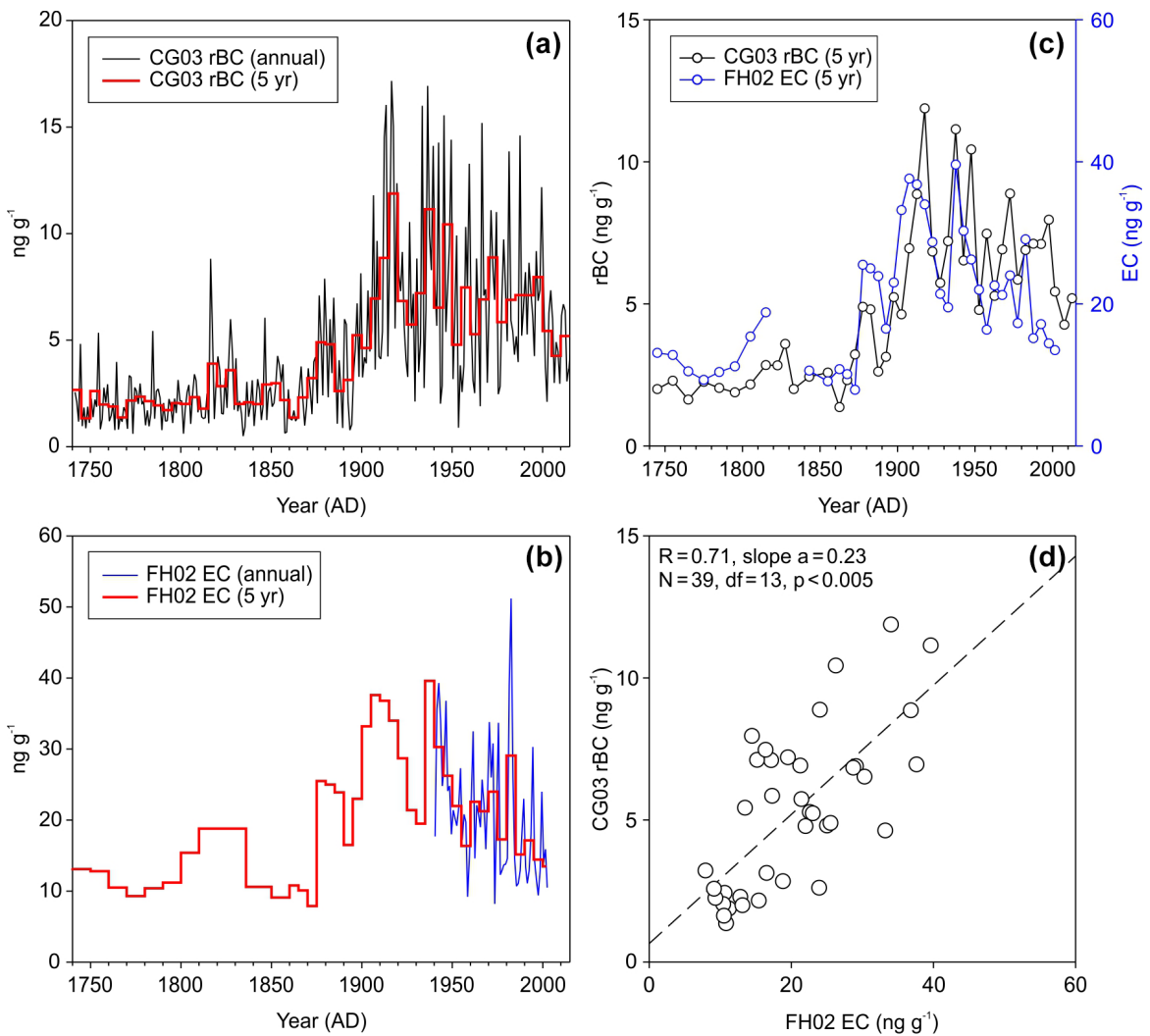

Figure 3. (a) Colle Gnifetti CG03 rBC concentrations and (b) Fiescherhorn FH02 elemental carbon (EC) concentrations (Jenk et al., 2006; Cao et al., 2013; Gabbi et al., 2015); (c) comparison of CG03 and FH02 ice cores resampled to the FH02 sampling resolution of 5-10 years with (d) linear fit and Pearson's correlation coefficient $R=0.71, P<0.005$ (adjusted for a reduced sample size owing to autocorrelation of the data sets) indicated.

Table 2. Median concentrations for selected chemical and elemental tracers from Colle Gnifetti during pre-industrial (PI), during time periods dominated by the fossil-fuel sources coal (COAL) and petroleum products (PETROLEUM).

\begin{tabular}{|c|c|c|c|c|c|c|c|}
\hline & $\begin{array}{r}1741-1850 \\
\text { PI }\end{array}$ & $\begin{array}{r}1901-1950 \\
\text { COAL }\end{array}$ & $\begin{array}{r}\text { 1951-1993 } \\
\text { PETROLEUM }\end{array}$ & COAL/PI & PETROLEUM/PI & Main sources & Main emitters \\
\hline $\mathrm{BC}$ & 1.9 & 7.2 & 6.6 & 3.7 & 3.4 & $\mathrm{cb}$, ind, t, bb, ff & Natural + anthropogenic \\
\hline $\mathrm{NH}_{4}^{+}$ & 34 & 66 & 131 & 2.0 & 3.9 & $\mathrm{a}, \mathrm{bb}, \mathrm{ff}, \mathrm{b}$ & Natural + anthropogenic \\
\hline $\mathrm{SO}_{4}^{2-}$ & 80 & 284 & 679 & 3.6 & 8.5 & ind, t, cb, d, vol & Natural + anthropogenic \\
\hline $\mathrm{Pb}$ & 0.11 & 0.55 & 1.32 & 5.1 & 12.3 & $\mathrm{t}$, ind, cb & Anthropogenic \\
\hline $\mathrm{Bi}$ & 1.2 & 4.4 & 3.6 & 3.7 & 3.0 & $\mathrm{cb}$, ind, $\mathrm{t}$ & Anthropogenic \\
\hline $\mathrm{NO}_{3}^{-}$ & 80 & 100 & 251 & 1.3 & 3.1 & ind, $\mathrm{t}$ & Natural + anthropogenic \\
\hline $\mathrm{Na}^{+}$ & 17.1 & 17.3 & 18.9 & 1.0 & 1.1 & ss, $\mathrm{d}$ & Natural \\
\hline $\mathrm{Ca}^{2+}$ & 68 & 102 & 118 & 1.5 & 1.7 & $\mathrm{~d}$ & Natural \\
\hline
\end{tabular}

All concentrations are median concentrations in $\mathrm{ng} \mathrm{g}^{-1}$, except Bi $\left(\mathrm{pg} \mathrm{g}^{-1}\right)$; calcium, sulfate, sodium and nitrate values are the mean from both ice cores CG03A and CG03B BC is from CG03B, all others are from CG03A. cb: coal burning; ind: industrial; t: traffic; bb: biomass burning; ff: forest fires; a: agriculture; b: biogenic; ss: sea salt; d: mineral dust; vol: volcano.

tively. AD 1993 marks the end of the time period for which continuous trace element analyses were performed.

In the pre-industrial period, ammonium $(R=0.75, p<$ $0.0001)$ and nitrate (not shown) are strongly correlated with $\mathrm{rBC}$, indicating that $\mathrm{BC}$ was associated with (natural or an- thropogenic) biomass burning emissions (Figs. 4 and S6). Sulfate $\left(\mathrm{SO}_{4}^{2-}\right)$ concentrations started to rise in AD 1900 , with this timing well constrained by the Saharan dust event of AD 1901 (Oeschger, 1977; Wagenbach and Geis, 1989). Throughout the COAL era $\mathrm{SO}_{4}^{2-}$ concentrations are strongly 
correlated with $\mathrm{rBC}$, with this correlation becoming weaker during the PETROLEUM era. Heavy metals such as lead $(\mathrm{Pb})$ and $\mathrm{Bi}$ show high relative enrichments, comparable to $\mathrm{rBC}$ in particular, from AD 1910 to 1950 indicating an increased association of $\mathrm{BC}$ with anthropogenic fossil-fuel emissions (e.g. coal burning) during that time (Table 2). None of the four discussed industrial pollution tracers $(\mathrm{rBC}$, $\mathrm{SO}_{4}^{2-}, \mathrm{Pb}, \mathrm{Bi}$ ) show pronounced increases in concentrations starting in the mid-19th century. In agreement with other dust records from Colle Gnifetti (Bohleber et al., 2018; Wagenbach and Geis, 1989), we observe no enhanced mean (or frequency) of mineral dust deposition throughout the 19th century (Figs. S1, S4). Only during the past three decades (AD 1975-2015), does the dust activity appear to be anomalously high with respect to the long-term variability (Figs. S6), which is thought to relate to increased drought conditions in the main dust source regions in northern Africa (Moulin and Chiapello, 2006).

\subsection{Comparison to other ice-core $\mathrm{BC}$ records}

Few other ice-core records contain precisely dated information about Central European industrial BC emissions for the 19th century. Previous determinations of EC concentrations from the Colle Gnifetti ice core with various methods are characterized by coarse resolution and unknown reproducibility (Lavanchy et al., 1999; Thevenon et al., 2009). The Fiescherhorn FH02 ice core obtained $70 \mathrm{~km}$ north of CG03 in the Bernese Alps ( 3900 m a.s.l., $46^{\circ} 33^{\prime} 03^{\prime \prime} \mathrm{N}$; $08^{\circ} 04^{\prime} 00^{\prime \prime} \mathrm{E}$ ) provides total EC concentrations from AD 1650 to 1940 at 5-10-year resolution (Fig. 3b) (Jenk et al., 2006) and analyses were recently completed at annual resolution until AD 2002 (Cao et al., 2013; Gabbi et al., 2015). The lowresolution record from Fiescherhorn (Jenk et al., 2006) and Colle Gnifetti (Thevenon et al., 2009) were used by Painter et al. (2013) as input for their model study on potential changes of 19th century snow albedo (note that in Fig. 2 in Painter et al., 2013, the labelling of the two cores was swapped). Despite the coarse resolution, the overall EC trend from Fiescherhorn ice core is closely reproduced by the new rBC record from CG03 ( $R=0.71, p<0.005)$ (Fig. 3c, d). Differences in absolute concentrations by approximately a factor of four can be understood to reflect a difference in elevation (FH02 is situated $500 \mathrm{~m}$ lower in elevation and closer to the emission sources) and a difference in the analytical methods employed, with thermo-optical methods resulting in consistently higher values compared to photometric determination of rBC (Currie et al., 2002; Lim et al., 2014) (also see Sect. 4.1). Nevertheless, the common three-step increase of concentrations occurring around AD 1875, 1900, and 1940, strongly supports the interpretation that both ice cores capture a common signal of industrial $\mathrm{BC}$ emissions increase driven by technological and economic developments in Central Europe.

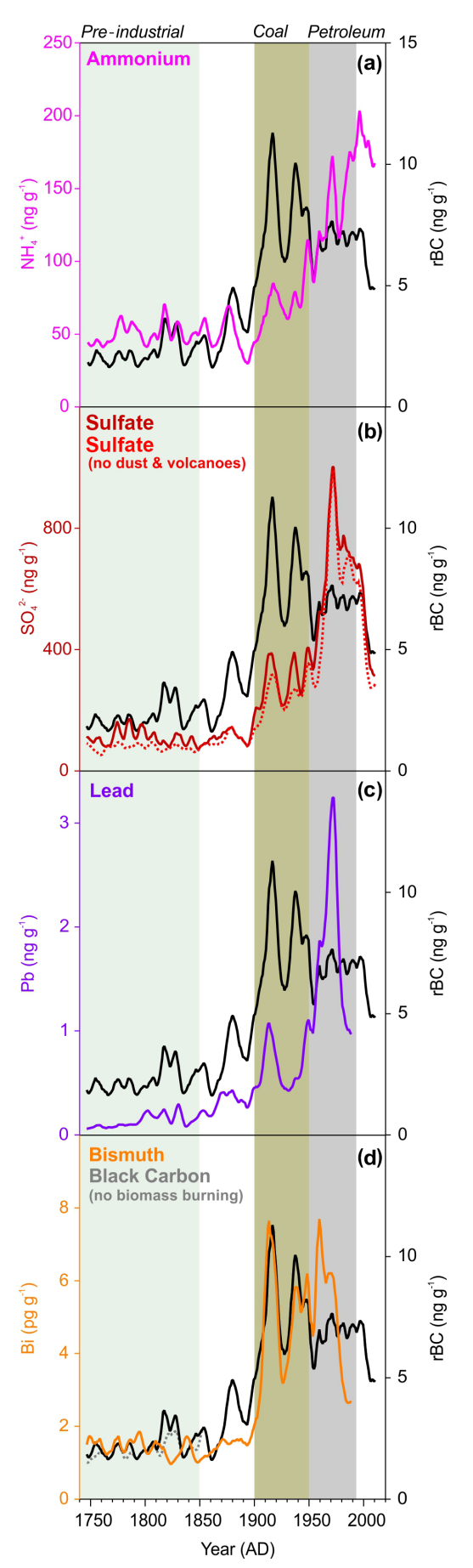

Figure 4. Colle Gnifetti rBC record (black) compared with (a) ammonium $\left(\mathrm{NH}_{4}^{+}\right)$, (b) total sulfate $\left(\mathrm{SO}_{4}^{2-}\right)$ and sulfate corrected for contributions from volcanic emissions and Saharan dust (dotted line), (c) lead $(\mathrm{Pb})$, and (d) bismuth (Bi) together with $\mathrm{rBC}$ corrected for biomass burning contributions $\left(\mathrm{BC}_{\mathrm{no}} \mathrm{BB}\right.$; grey dotted line). All records are 11-year filtered. Marked are time periods dominated by pre-industrial emissions (AD 1741-1850), coal burning (AD 19011950) and petroleum burning emissions (AD 1951-1993), respectively. 
In contrast, the low-resolution EC record of Thevenon et al. (2009) - characterized by varying time resolution and without demonstrated repeatability of the results - shows a markedly different variation in time. As the age-model used by Thevenon et al. (2009) was not forced to intersect with the absolute dated reference horizons, it is biased from the annual-layer dated chronology by, on average, 14 years (7-18 years) during the 19th century (Fig. S7). The final chronology dates the early $\sim \mathrm{AD} 1850$ increase in EC in the 1830s, which would imply an early start of industrialization. This is neither consistent with the new rBC record from Colle Gnifetti or with the Fiescherhorn EC record nor with $\mathrm{rBC}$ records from Greenland (see below). Given that mean 16th century EC concentrations reach comparable levels during the peak industrial era of the 20th century, we speculate that the Thevenon et al. (2009) EC record suffered from methodological biases, probably related to the presence of mineral dust (i.e. high EC concentrations occurred often in samples with high dust concentrations, see Fig. 3 in Thevenon et al., 2009).

The non-BB $\mathrm{rBC}$ record ( $\mathrm{CG03} \mathrm{rBC}_{\text {no } \mathrm{BB}}$ ) was compared to an equivalent stacked $\mathrm{rBC}_{\mathrm{no}} \mathrm{BB}$ record obtained from four ice cores (Summit 2010, D4, NEEM-2011-S1, TUNU2013; Fig. 5) from Greenland (Keegan et al., 2014; McConnell et al., 2007; Mernild et al., 2015; Sigl et al., 2013, 2015) acknowledging that these Greenland ice cores capture a mixture of emissions from both northern America and Europe (Bauer et al., 2013; Hirdman et al., 2010; Lamarque et al., 2013; McConnell et al., 2018). Due to high snow accumulation rates and analysed at high-resolution, absolute dating uncertainties for these records are estimated to be better than \pm 1 year, which provides us with another independent, highprecision age constraint for the onset of increased industrial BC emissions from Europe.

Whereas absolute concentrations are, depending on the specific industrial pollutant (BC, Bi), a factor of 2-4 lower in Greenland, the long-term trends are remarkably similar between the Greenland stack and CG03 (Figs. 4d, 5). Overall, concentrations of major industrial pollutants appeared to have increased earlier by roughly 10 years (in AD 1890) in Greenland compared to the Alps, most prominently visible in bismuth. This delay is consistent with industrialization having accelerated earlier in North America (McConnell and Edwards, 2008) than in the major Central European countries (e.g. Germany, Italy, France). The maximum in industrial $\mathrm{BC}$ emissions were synchronous between Greenland and the Alps, both peaking at approximately AD 1915. Differences exist in the long-term trends of rBC since the early 20th century maximum, with Greenland values closely approaching pre-industrial levels while remaining elevated in the Alps.

\subsection{Comparison with BC emission inventories}

We compare our ice-core based deposition history with estimated emissions of BC from fossil-fuel and bio-fuel burn-
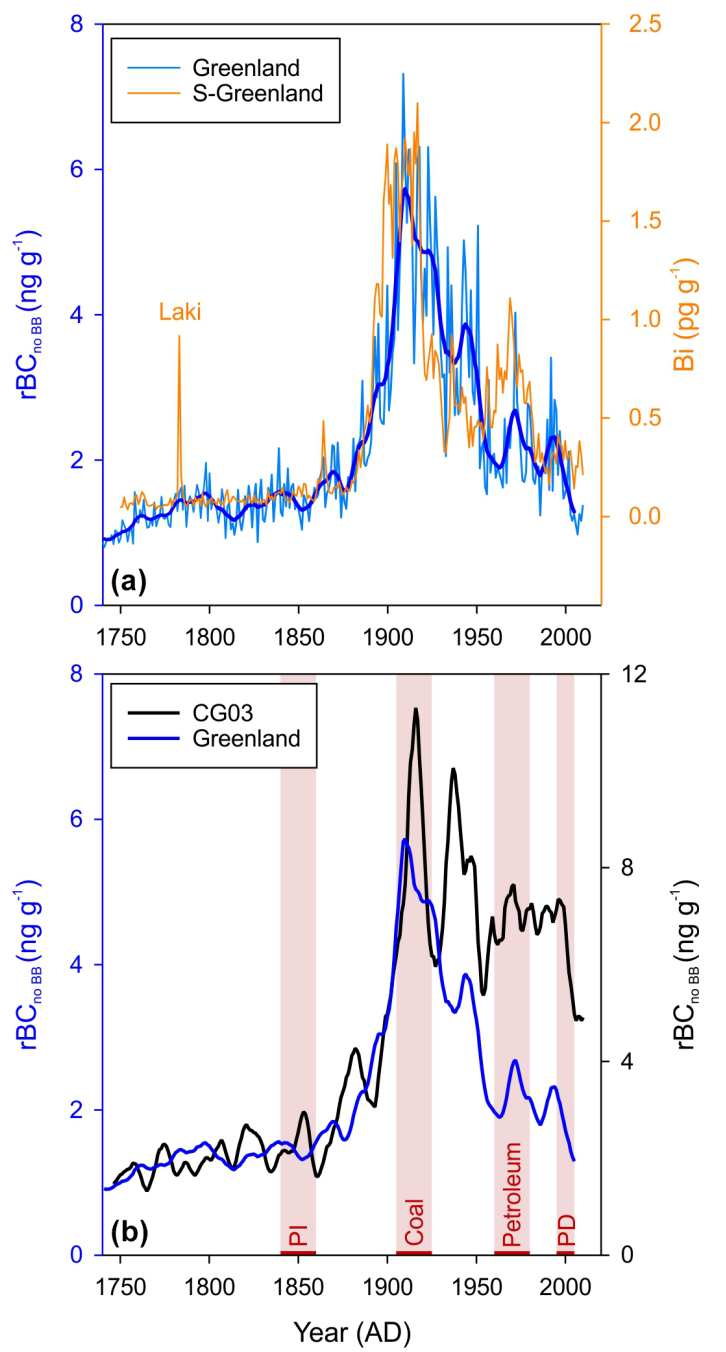

Figure 5. (a) Stacked $\mathrm{rBC}$ record from Greenland including the four ice cores NEEM-2011-S1, D4, TUNU2013, and Summit2010 (Keegan et al., 2014; McConnell et al., 2007; Mernild et al., 2015; Sigl et al., 2013, 2015) and (orange) a stacked Bi record from the South Greenland ice cores (Chellman et al., 2017) . Samples influenced by forest fire and biomass burning (BB) activity were replaced by the corresponding 21-year running median before smoothing the record with an 11-year filter (thick blue line). BB activity detection is based on co-registered vanillic acid (for D4; McConnell et al., 2007) and on an outlier detection algorithm previously employed for discrimination of fire activity and volcano detection in Greenland ice cores (Fischer et al., 2015; Sigl et al., 2013). (b) Stacked $\mathrm{rBC}_{\text {no }} \mathrm{BB}$ record from Greenland and $\mathrm{CG}_{03}$ no BB record. Mean $\mathrm{rBC}_{\mathrm{no}} \mathrm{BB}$ concentrations and relative enrichment to pre-industrial (PI) are provided for specific age windows marked by red shading (summarized in Table 3) dominated by coal-burning, petroleum-product burning, and present day (PD) emissions. 
Table 3. Estimated BC emissions from Bond et al. (2007) for OECD Europe and Western Alps (45-47 $7^{\circ}$, 6-9 ${ }^{\circ}$ E) with median concentrations of CG03 rBC and FH02 EC during pre-industrial (PI, 1840-1860), during peak coal burning (1910-1950), peak petroleum burning (1970-2000) and present day (PD, 1995-2005); numbers in brackets indicate the increase relative to PI (in \%) (see Fig. 6).

\begin{tabular}{lrrrr}
\hline & $\begin{array}{r}\text { pre-industrial (PI) } \\
1840-1860\end{array}$ & $\begin{array}{r}\text { "Peak coal" } \\
1905-1925\end{array}$ & $\begin{array}{r}\text { "Peak petroleum" } \\
1960-1980\end{array}$ & $\begin{array}{r}\text { Present day (PD) } \\
1995-2005\end{array}$ \\
\hline Ice cores $\left[\mathrm{ng} \mathrm{g}^{-1}\right]$ & & & & \\
\hline CG03 & 2.3 & $8.4(+270 \%)$ & $6.6(+190 \%)$ & $6.6(+190 \%)$ \\
FH02 & 9.9 & $34.8(+250 \%)$ & $21.0(+110 \%)$ & $14.1(+43 \%)$ \\
Greenland stack $(N=4)$ & 1.4 & $5.2(+270 \%)$ & $2.3(+59 \%)$ & $1.8(+24 \%)$ \\
\hline Emission inventory $\left(\right.$ Bond et al., 2007) $\left[\mathrm{Gg} \mathrm{yr}^{-1}\right]$ & & & $352(+20 \%)$ \\
\hline OECD Europe & 292 & $793(+170 \%)$ & $653(+120 \%)$ & $5.7(+79 \%)$ \\
Western Alps $\left(45-47^{\circ} \mathrm{N} / 6-9^{\circ} \mathrm{E}\right)$ & 3.2 & $8.9(+180 \%)$ & $8.0(+150 \%)$ &
\end{tabular}

Table 4. Alpine glacier lengths during the emergence of industrial BC deposition (see Fig. 7).

\begin{tabular}{lrrrr}
\hline & $\begin{array}{r}\text { Time-of- } \\
\text { emergence }\end{array}$ & $\begin{array}{r}\text { Total 5\%-95\% range } \\
( \pm 5 \text {-year dating uncertainty) }\end{array}$ & $\begin{array}{r}\text { Bayesian } \\
\text { change-point }\end{array}$ & $\begin{array}{r}\text { Total 5\%-95\% range } \\
( \pm 5 \text {-year dating uncertainty) }\end{array}$ \\
\hline Year & 1875 & {$[1868-1884]$} & 1876 & {$[1870-1881]$} \\
\hline \% of total mid-19th century (i.e. 1850-1880) glacier length reduction completed & 100 & {$[83-100]$} \\
\hline Bossons & 100 & {$[78-100]$} & 84 & {$[56-92]$} \\
Mer De Glace & 79 & {$[37-89]$} & 87 & {$[62-90]$} \\
O. Grindelwald & 83 & {$[53-89]$} & 76 & {$[63-94]$} \\
U. Grindelwald & 74 & {$[54-100]$} & 85 & {$[63-91]$} \\
Stack $(N=4)$ & 82 & {$[52-92]$} & 86 & {$[62-93]$} \\
Median $(N=4)$ & 81 & {$[54-94]$} & & \\
\hline
\end{tabular}

ing (Bond et al., 2007) which form the main input for simulating BC climate effects (direct, indirect aerosol, and icealbedo forcing) on past climate (Flanner et al., 2007; Lamarque et al., 2013; Shindell et al., 2013). We notice that the general structure of $\mathrm{BC}$ and $\mathrm{EC}$ from the two Alpine ice cores closely resembles estimated $\mathrm{BC}$ emissions for both OECD Europe and the western Alpine region taken from the bottomup inventory of Bond et al. (2007) (Fig. 6). Interpreting the ice-core long-term trends as proxies for atmospheric burden (or emissions, respectively) we identify three major differences between these datasets. First, the increase in BC to its early 20th century maximum, as deduced from the ice cores, occurred in two subsequent steps, whereas the emission inventory implies a more gradual increase throughout the 19 th and early 20th century. Second, the BC inventory emissions remain fairly steady at high levels from AD 1910 to 1950 with no decrease between the two world wars as in both Alpine ice cores, and to some degree also in the Greenland ice cores (Fig. 5). Third, the emission inventories suggest that BC emissions dropped significantly since the $1960 \mathrm{~s}$ and reached for OECD Europe pre-industrial levels by 1980 , whereas $\mathrm{BC}$ ice-core concentrations remained clearly above their pre-industrial values until the very recent past. Median concentrations from 1980 onwards are still 3-fold at CG03 and 1.5-fold at FH02 compared to pre-industrial AD 17411850 levels, respectively. Table 3 summarizes BC emission estimates based on inventories and mean ice-core rBC concentrations centred at AD 1850, 1915, 1975, and 2000 for CG03, FH02 and a Greenland ice-core stack, respectively.

\subsection{The timing of industrial $\mathrm{BC}$ deposition and glacier length variations in Europe in the 19th century}

To test the plausibility of an ice-albedo effect to force (or at least contribute) to the glacier length reductions occurring during the 19th century we here examine the exact timing of industrial BC deposition at Colle Gnifetti and Fiescherhorn. For the latter, we interpret the sharp increase in EC (Fig. 3) in the sample dated to the years AD 1875 to 1879 (Jenk et al., 2006). Assuming conservatively that the increase occurred at the start age of this discrete sample and considering a dating uncertainty of \pm 5 years provides us with a lower bound for the earliest occurrence of enhanced $\mathrm{BC}$ deposition of $\mathrm{AD} 1870$. ToE analysis for the $\mathrm{CG} 03 \mathrm{rBC}_{\mathrm{no}} \mathrm{BB}$ record identifies the year AD 1875[5\%-95\% range: AD 1870-1882] as 

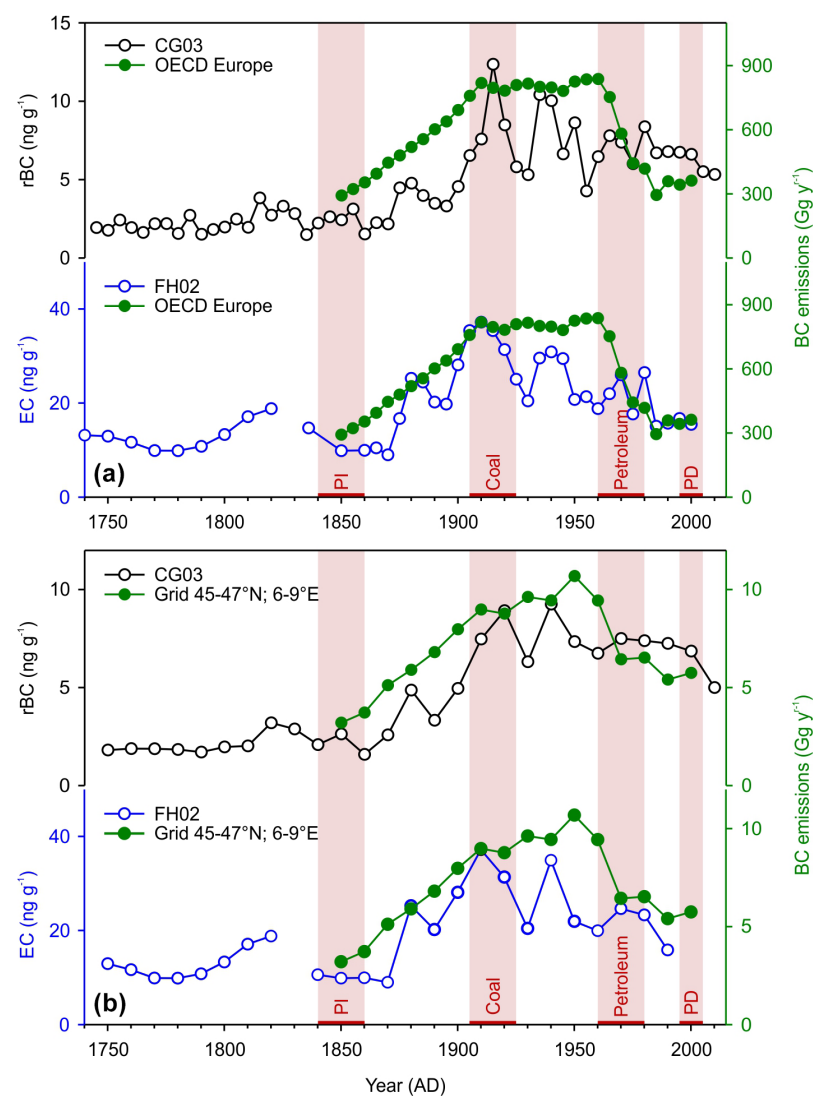

the Bayesian change-point method (AD 1891), respectively (Fig. S8)

The four high-resolution glacier length records indicate that in $\mathrm{AD} 1875$ these glaciers had already completed the majority of their total cumulative length reductions (i.e. maximum to minimum front position) of the second half of the 19th century. Bossons had experienced $100 \%$, Oberer and Unterer Grindelwald $83 \%$ and $74 \%$, respectively, and Mer de Glace $79 \%$, of their cumulative length losses (Table 4; Fig. 6e), with differences likely explained by the different size and topography of the individual glaciers (Lüthi, 2014). Consequently, the stacked record of all four glacier terminus position curves reveals that the highest annual mean glacier length reduction rates of $>40 \mathrm{~m}$ year $^{-1}$ occurred during the 1860s, when $\mathrm{BC}$ concentrations in both ice-cores were still indistinguishable from their natural background levels (Fig. 7). During time-of-emergence of industrial BC deposition in AD 1875 the stacked glacier record had experienced $83 \%$ [52\%-92\%] of its entire cumulative glacier retreat from the maximum 1850s terminus positions. ToE analyses performed for total BC (ToE: AD 1890) and for calcium (ToE: AD 1986) are equally inconsistent with a mid19th century emergence of the light-absorbing impurity content on Alpine glaciers outside the range of natural variability (Figs. S9, S10).

\section{Discussion}

Figure 6. (a) $\mathrm{CG} 03 \mathrm{rBC}$ and $\mathrm{FH} 02 \mathrm{EC}$ concentrations and energyconsumption based $\mathrm{BC}$ emission estimates from fossil fuel and biofuel burning (Bond et al., 2007) for OECD Europe and (b) for the grid cells $45-47^{\circ} \mathrm{N}$ and $6-9^{\circ} \mathrm{E}$ encompassing the locations of the ice-core drilling sites and the four glacier observation records in the Western Alps (see Fig. 1). Mean $\mathrm{rBC}_{\text {no }} \mathrm{BB}$ concentrations and relative enrichment to pre-industrial (PI) are provided for specific age windows marked by red shading (summarized in Table 3 ) dominated by coal-burning, petroleum-product burning and present day (PD) emissions.

the time of emergence of industrial BC deposition with a conservative dating uncertainty of \pm 5 years (Fig. 7, Table 4). As $\mathrm{ToE}$ and dating uncertainty are independent, we estimate the absolute uncertainty range in the timing of industrial $\mathrm{BC}$ deposition at CG03 as AD 1868-1884 (5\%-95\% range). The Bayesian change-point algorithm returns virtually the same result, with the highest change point probability in AD 1876 (Table 4). The median timing of industrial BC deposition at the four Greenland ice-core sites is AD 1872 (ToE analysis) or AD 1891 (Bayesian change-point), respectively, in good agreement with the Alpine ice cores. Using the precisely dated D4 ice core and vanillic acid to discriminate forest fire emissions, McConnell et al. (2007) gave AD 1888 as their best estimate for industrial $\mathrm{BC}$ emergence, closely matching our best estimates, employing ToE analysis (AD 1878) and 


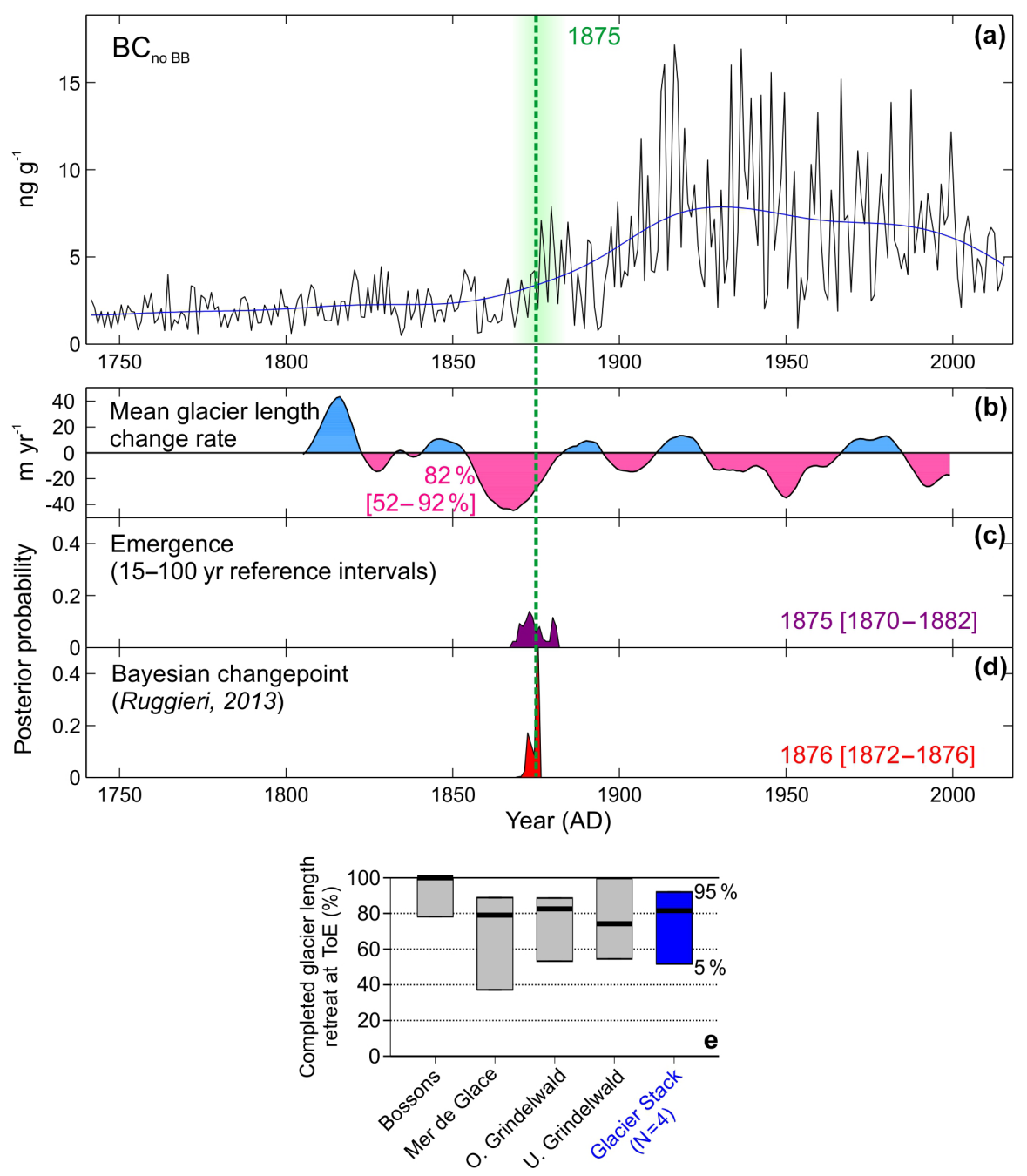

Figure 7. (a) Annual CG03 non-biomass burning rBC concentrations ( $\mathrm{BC}_{\mathrm{no}} \mathrm{BB}$, black) with 15-year filtered trend; (b) mean glacier length change rate (smoothed with a 11-year filter) of the stacked $(N=4)$ glacier length records from Bossons, Mer de Glace, Oberer Grindelwald, and Unterer Grindelwald glaciers; (c) normalized distribution of the probabilities of the timing of emergence of industrial $\mathrm{BC}$ deposition assessed across 15-100 year windows using time-of-emergence (ToE) analysis (Hawkins and Sutton, 2012) and (d) using a linear Bayesian change-point algorithm (Ruggieri, 2013). Panels (c, d) give the values for the change points, showing the median [5\%-95\% range], or in the case of the Bayesian change-point method the mode [5\%-95\%]. The dashed green line across panels (a-d) represents the median of the ToE analysis. The red area left of the intersect of the mean glacier length change rate curve. Panel (b) indicates the completed cumulative length reduction since the 1850 s maximum until ToE in 1875 and the $5 \%-95 \%$ range taking also into account an absolute dating uncertainty of \pm 5 years; (e) completed glacier length reductions since the mid-1850s maximum for the four individual glaciers and the stack (black bars are for the year 1875) with $5 \%-95 \%$ total uncertainty range.

Bi) occurred before AD 1870 (Fig. 5). Mineral dust deposition at $\mathrm{CG03}$ does not show relevant long-term trends during the 19th century.

The new combined evidence strongly contradicts the previous key assumption of a synchroneity between glacier retreat in the European Alps and BC increase in the 19th century in apparent support of the hypothesis that industrial $\mathrm{BC}$ emissions have forced accelerated glacier melt through a snow-albedo feedback (Painter et al., 2013). 82\% [52\%] of the glacier length reductions had already occurred at the best [earliest] estimated time of emergence of industrial $\mathrm{BC}$ deposition (Fig. 7). The discrepancy in the temporal relation between our results and those of Painter et al. (2013) are in part explained by the low resolution in their deployed glacier length records in the 19th century (i.e. Rhône, Argentière), that tend to smooth the actual terminus position curves between AD 1850 and 1900 and also by the limited quality of the BC records available at that time (see Sects. 1 and 3.2). As shown in Fig. 8, retreat rates of the terminus positions from high-resolution glacier observations 

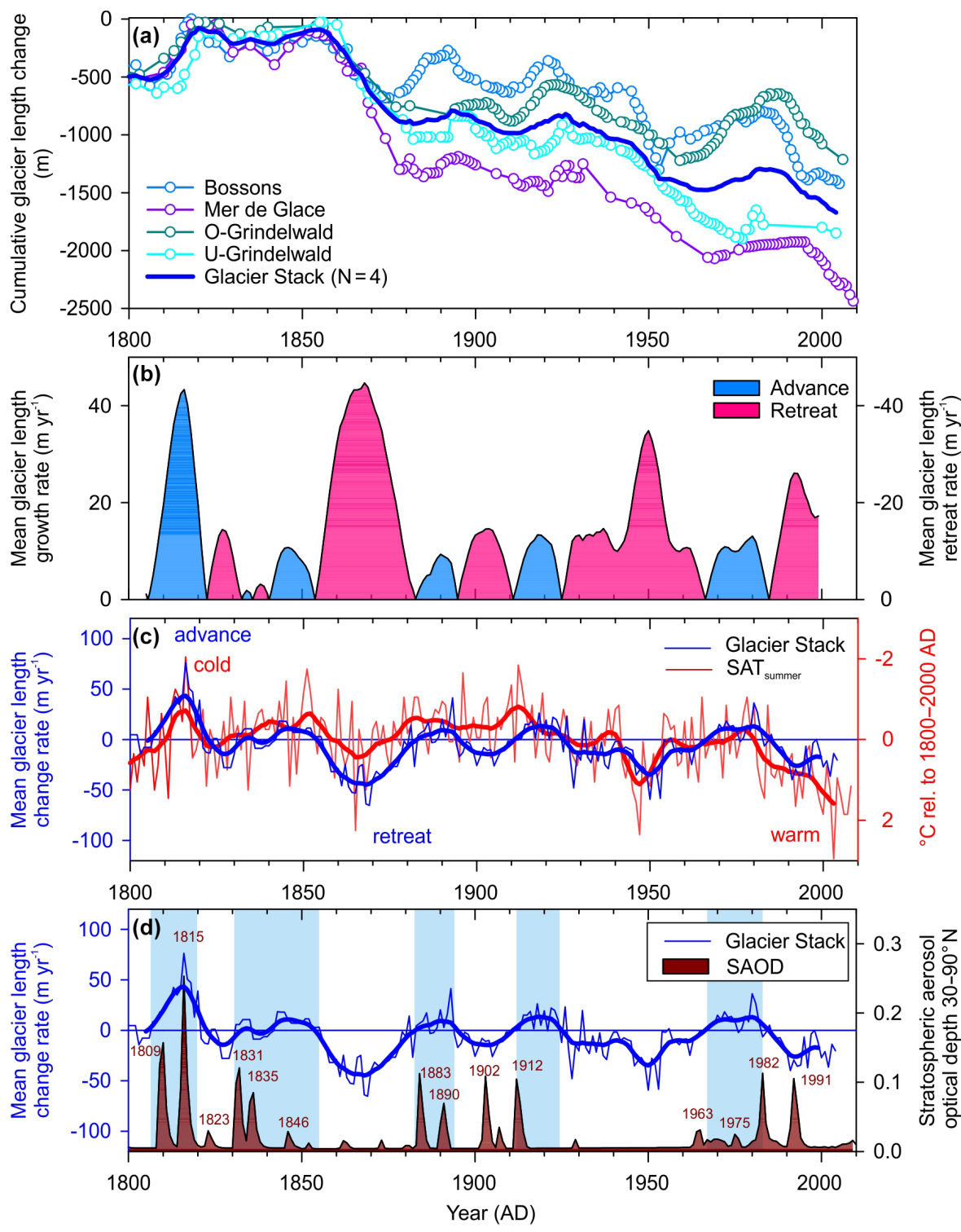

Figure 8. (a) Cumulative glacier length changes for the four glaciers Bossons, Mer de Glace, Oberer (O-) Grindelwald and Unterer (U-) Grindelwald and their average (glacier stack; missing observations were filled using linear interpolation); (b) mean glacier length change rate (smoothed with a 11-year filter) of the glacier stack length record indicating phases of average glacier advances (blue shading) and of glacier retreat (red shading), respectively; (c) smoothed and annual resolution mean glacier length change rates of the glacier stack and equally resolved surface air temperature anomalies for the summer half year $\left(\mathrm{SAT}_{\text {summer }}\right.$ ) from the Greater Alpine Region HISTALP station network (Böhm et al., 2010); Panel (d) is as in(c) but with stratospheric aerosol optical depth (SAOD) at 550 nm based on ice cores (1800-1850: Toohey and Sigl, 2017) merged with the CMIP6 (version 2) reconstruction (1850-2000: Luo, 2016; Eyring et al., 2016).

were much stronger between $\mathrm{AD} 1850$ and 1875 than they were between AD 1875 and 1900. Moreover, when industrial $\mathrm{BC}$ emissions reached their overall maximum values in the 1910-20s, indicated by ice-core BC concentrations exceeding 5 times their pre-industrial values, Alpine glaciers showed no indications of further retreat, but were instead advancing again (Figs. 7, 8). As our $\mathrm{rBC}$ measurement technique is less sensitive to "brown carbon" and mixed component aerosols and larger compounds outside the detectable size range (up to mass-equivalent diameter of $800 \mathrm{~nm}$ ) such as produced by burning low quality coal or inefficient coal combustion (Sun et al., 2017), this record alone cannot rule out a potential role for other light-absorbing aerosols. However, these compounds are measured by the method applied for the EC record from $\mathrm{FH} 02$ which shows very good agreement with the $\mathrm{rBC}$ record from Colle Gnifetti (Sect. 3.2). This suggests that factors other than changes in surface snow albedo, such as temperature and seasonal precipitation dis- 
Table 5. Alpine glacier advances and volcanic eruption dates and resulting stratospheric aerosol properties (see Fig. 8).

\begin{tabular}{lrrl}
\hline $\begin{array}{l}\text { Major glacier } \\
\text { advance phases (AD) }\end{array}$ & $\begin{array}{r}\text { Cumulative glacier } \\
\text { length change }(\mathrm{m})\end{array}$ & $\begin{array}{r}\mathrm{SAOD}_{30-90^{\circ} \mathrm{N} \text { rel. }} \\
\text { to AD 1900-2000 }(\%)\end{array}$ & $\begin{array}{l}\left.\text { Major eruptions (SAOD } 30-90^{\circ} \mathrm{N}>0.02\right) \\
\text { [Rank among all eruptions in AD 1800-2000] }\end{array}$ \\
\hline $1807-1820$ & +450 & $+320 \%$ & $1809[2] ; 1815[1]$ \\
$1831-1854$ & +126 & $+58 \%$ & $1831[3] ; 1835[9] ; 1846[14]$ \\
$1883-1893$ & +115 & $+109 \%$ & $1883[5] ; 1890[10]$ \\
$1913-1924$ & +154 & $-20 \%$ & $1902[6] ; 1907[11] ; 1912[8]$ \\
& & $+143 \%($ lag -10 years) & \\
$1967-1982$ & +183 & $0 \%$ & $1963[12] ; 1975[15] ; 1982[4]$ \\
\hline
\end{tabular}

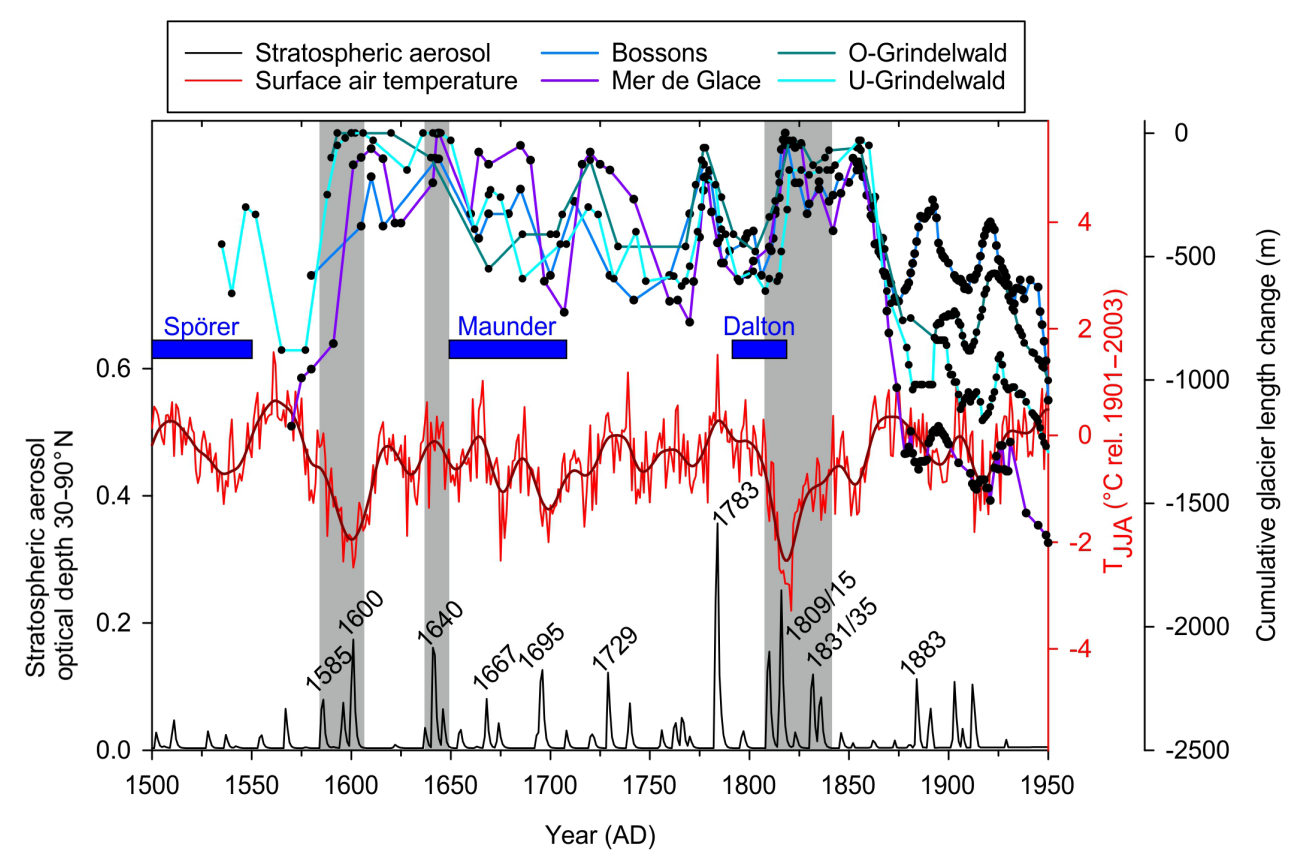

Figure 9. Cumulative glacier length changes for the four glaciers Bossons, Mer de Glace, Oberer (O-) Grindelwald and Unterer (U-) Grindelwald with black dots marking years with observations (Nussbaumer and Zumbühl, 2012), tree-ring reconstructed Alpine summer (JJA) temperatures (Büntgen et al., 2011), minima in solar activity (Usoskin, 2017), and volcanic aerosol forcing (Revell et al., 2017; Toohey and Sigl, 2017) from AD 1500 to 1950 . Grey shading marks time periods with increased volcanic aerosol forcing.

tribution (Steiner et al., 2008; Zumbühl et al., 2008), may have dominated mass balance and glacier length variability of these European glaciers until at least AD 1875. The previously made claim (Painter et al., 2013; Vincent et al., 2005) that precipitation and temperature variability alone were insufficient to explain the observed glacier length variability has been recently challenged by Lüthi (2014) and Solomina et al. (2016), who demonstrated that on a regional to global scale summer temperatures are the most important parameters determining glacier mass balance variability. Previously underestimated due to an "early instrumental warm bias" (Böhm et al., 2010; Frank et al., 2007), new surface air temperature (SAT) reconstructions based on early instrumental records, historical documentary proxy evidence, and tree-rings now all give evidence that the early 19th century was exceptionally cold in Central Europe in a long-term con- text (Brohan et al., 2012; Büntgen et al., 2011; Luterbacher et al., 2016) (Figs. 9, S11). A strong negative radiative forcing resulting from at least five large tropical eruptions between 1809 and 1835 (Sigl et al., 2015; Toohey and Sigl, 2017), in tandem with the Dalton solar minimum (Jungclaus et al., 2017; Usoskin, 2013) appeared to have forced the glaciers to strongly advance until the $1850 \mathrm{~s}$, in some cases probably far outside their range of typical long-term natural variability (Fig. 8). Similarly, later glacier advances (e.g. in the 1890s and 1910s) followed other major volcanic eruptions including Krakatau (1883) and Katmai (1912) (Table 5).

A strong role of volcanic forcing is supported by a consistent strong coherence of glacier expansions following clusters of volcanic eruptions throughout the past 2000 years (Le Roy et al., 2015; Solomina et al., 2016). The stratospheric aerosol burden for the time window AD 1600-1840 
was $40 \%$ larger than during the entire Common Era (Sigl and Toohey, 2017) with volcanic eruptions frequently forcing cold spells and glacier advances (e.g. in 1600s, 1640s, 1820s, 1840s) in the Alps (Fig. 9) and elsewhere (Solomina et al., 2016). Increased summer precipitation during cool post-volcanic summers may have additionally contributed to a more positive mass balance (Raible et al., 2016; Wegmann et al., 2014) plausibly enforced by a positive albedo feedback loop resulting from increased snow cover in the Alps. The glaciers' initial and more or less synchronous retreat from the maximum terminus positions starting at 1860 may be a delayed rebound back to their positions they had before the radiative perturbed time period AD 1600-1840 (Fig. 9), and an additional decrease of snow albedo from the deposition of BC is considered not to be needed to explain these observations (Lüthi, 2014). The specific extent to which early anthropogenic warming (Abram et al., 2016), changes in atmospheric modes (Swingedouw et al., 2017) including the Atlantic Multidecadal Oscillation (AMO; Huss et al., 2010), or snow-albedo feedbacks from increasing light-absorbing aerosol deposition towards the end of the 19th century may have contributed to the overall glacier length variability in the European Alps throughout the 19th century remains difficult to determine. Confidently attributing and quantifying the contribution of natural and anthropogenic forcing to observed glacier changes will require reconciliation of early instrumental and proxy climate data (Böhm et al., 2010; Frank et al., 2007), and the use of models to decompose the relative contribution of volcanic eruptions, light-absorbing impurities such as BC or other compounds (e.g. brown carbon, mineral dust), and other potential natural or anthropogenic contributions (Goosse et al., 2018; Zekollari et al., 2014).

\subsection{Constraints on Central European BC emissions}

While the CG03 rBC time series reproduces the general major emission trends well from gridded BC emission inventories (Fig. 6) and it provides additional structure that is currently not captured by the $\mathrm{BC}$ inventories. This includes a stepwise increase of $\mathrm{BC}$ rather than linearly rising emissions; a short reduction of emissions between the two world wars likely related to global economic depression (Gabrieli and Barbante, 2014; Schwikowski et al., 2004) and smaller reductions since the 1960s as opposed to the BC emission inventories. Similar to Europe, Greenland ice-core BC records also do not support the idea of a gradual increase in $\mathrm{BC}$ since AD 1850 but show a very rapid increase of emissions around AD 1890, suggesting that the emission inventories data before AD 1900 may be biased. This is plausible given the small number and incomplete nature of consumption and technology-related records contributing to these inventories during this time (Bond et al., 2007, 2004). As many datasets (e.g. refinery outputs) during the 19th century were only available for the USA and with extrapolation backward in time applied often when specific data was unavailable
(Bond et al., 2007) it is not surprising that the BC emission trend in Europe (and other regions) more or less closely follows that for North America prior to AD 1900 (Bond et al., 2007; Y. H. Lee et al., 2013). The discrepancy between the inventory-estimated and the much lower ice-core indicated reduction of BC in CG03 since the 1960s is striking. This mismatch suggests that the measures taken to reduce the release of $\mathrm{BC}$ into the atmosphere may not have been as efficient as the energy-consumption data suggests. This may hint that the emission factors (e.g. BC emitted per fossil-fuel unit burned) are frequently reported as too low in these inventories, which in the light of the Volkswagen emissions scandal revealed in 2015, seems at least a plausible scenario. A comparable offset had been recently also noted between modelled emissions and CG03 nitrate and ammonium records between 1995 and 2015 (Engardt et al., 2017) suggesting that besides rBC also $\mathrm{NO}_{x}$ and $\mathrm{NH}_{3}$ emissions may not be adequately accounted for in present-day emission inventories. Greenland ice cores capturing mostly emissions from North America (where diesel engines play a minor role compared to Europe) in contrast to the alpine ice cores show a very pronounced decrease of $\mathrm{BC}$ during the second half of the 20th century to almost pre-industrial values at present (Keegan et al., 2014; McConnell et al., 2007). While providing more realistic estimates of carbonaceous particle emissions from gasoline and diesel engines remains an area of ongoing research (Gentner et al., 2012, 2017; Platt et al., 2017) more records are certainly required from other suitable sites in Europe to elude the sources of this late 20th century mismatch. Further reducing uncertainties in ice-core $\mathrm{BC}$ records is of eminent importance in assessing the accuracy of emission inventories and of particular interest as all state-of-the-art coupled aerosol climate models use gridded BC emission inventories as input parameters for their simulations (Lamarque et al., 2010; Y. H. Lee et al., 2013; Shindell et al., 2013).

\section{Conclusion}

Industrial black carbon believed to be emitted in large quantities starting in the mid-19th century had been suggested as the key external forcing responsible for an accelerated melting of European glaciers through reductions in ice-albedo and subsequent ablation (Painter et al., 2013). We examined this interpretation by presenting new, highly resolved, well replicated ice-core measurements of refractory black carbon, mineral dust, and distinctive industrial pollution tracers from the Colle Gnifetti ice core in the Alps covering the past 270 years. The comprehensive suite of elemental and chemical species co-analysed enabled BC source attribution from industrial and biomass burning emissions. The precisely dated ice core allowed precise comparison of the timing of observed acceleration of glacier retreat in the mid19th century with that of increased deposition of black carbon on the glaciers caused by the industrialization in $\mathrm{Eu}-$ 
rope. Closely reproducing the main structure of the Fiescherhorn EC record (Jenk et al., 2006), our study suggests that at the time when European rBC emission rates started to significantly increase (only after 1870) the majority of Alpine glaciers had already experienced more than $80 \%$ of their total 19th century length reduction. Therefore, we argue that industrial BC emissions and subsequent deposition on Alpine glaciers are unlikely to be responsible for the rapid initial deglaciation at the end of the Little Ice Age in the Alps. We hypothesize that glacier length changes throughout the past 2000 years have been forced pre-dominantly by summer temperatures reductions induced by sulfuric acid aerosol forcing from large volcanic eruptions. In this sense, the retreat from the volcanically forced maximum glacier terminus positions starting in the 1860 s can be seen as a lagged response of the cryosphere after the volcanic induced cooling had reached its maximum following a sequence of major tropical eruptions in AD 1809, 1815, 1823, 1831 and 1835. Only after AD 1870, when BC emissions started to strongly increase, snow-albedo impurity effects may have potentially contributed to the glacier length reductions.

Much of the understanding of future climate change is based on model simulations, but models used to predict future climate must be evaluated against past climate for accuracy (Hansen et al., 2007; Lamarque et al., 2013). Aerosols in climate models are mostly evaluated with observations from the past few decades, time periods during which mitigation measures for air quality control were widely in place. Icecore records, possibly the only data sets to provide long-term historical information on aerosols, are thus critical for model evaluation, especially during time periods of widespread air pollution in industrialized countries during the 19th century. Here we present the first continuous BC record from Central Europe covering the past 270 years that has the resolution, precision, and reproducibility to serve in the future as a benchmark for climate models through dedicated model-data intercomparison (Koch et al., 2011; Y. H. Lee et al., 2013). Aerosol deposition at any single site also depends on factors such as atmospheric transport efficiency and the spatial distribution and conservation of snowfall. Incorporating more $\mathrm{BC}$ records from multiple sites into a stacked composite is expected to enhance the signal from the atmospheric burden over the noise caused by spatial variations in atmospheric transport and snow accumulation. Therefore, this should be considered a main focus for future research together with developing comparable records from other suitable ice-core sites in the Alps.

Data availability. The CG03 ice-core data are available in the PANGAEA repository, https://doi.org/10.1594/PANGAEA.894788 (Sigl et al., 2018).
Supplement. The supplement related to this article is available online at: https://doi.org/10.5194/tc-12-3311-2018-supplement.

Author contributions. MiS conceived this study, performed BC and ion analyses, developed age-models, analysed data, and wrote the paper; NJA performed ToE analyses; JG analysed trace elements, DO helped processing ice cores and developed SP2 methodology, TMJ supervised the development of the SP2 method and led the 2015 CG ice-core drilling campaign, MaS coordinated the project, and MiS led the manuscript writing with input from all coauthors.

Competing interests. The authors declare that they have no conflict of interest.

Acknowledgements. This work was supported by the Swiss National Science Foundation through the research program "Paleo fires from high-alpine ice cores" (CRSII2_154450/1). It was fostered by participation in the Volcanic Impacts on Climate and Society (VICS) working group of PAGES (Past Global Changes). The authors thank Joe R. McConnell and Nathan Chellman for providing Greenland ice-core data; Matt Toohey for providing SAOD reconstructions; Samuel Nussbaumer for providing glacier length reconstructions; Fang Cao for providing the FH02 EC record; Carlo Barbante for partly funding the CG03 drilling campaign; Sabina Brütsch for ion chromatography analyses; and all members of the CG ice-core drilling expeditions in 2003, 2008 and 2015. We also would like to thank Thomas Painter and colleagues and the three anonymous reviewers for their comments and valuable input helping to improve the manuscript.

Edited by: Becky Alexander

Reviewed by: three anonymous referees

\section{References}

Abram, N. J., McGregor, H. V., Tierney, J. E., Evans, M. N., McKay, N. P., Kaufman, D. S., and Consortium, P. K.: Early onset of industrial-era warming across the oceans and continents, Nature, 536, 411-418, 2016.

Barbante, C., Schwikowski, M., Döring, T., Gaggeler, H. W., Schotterer, U., Tobler, L., Van De Velde, K., Ferrari, C., Cozzi, G., Turetta, A., Rosman, K., Bolshov, M., Capodaglio, G., Cescon, P., and Boutron, C.: Historical record of European emissions of heavy metals to the atmosphere since the 1650s from Alpine snow/ice cores drilled near Monte Rosa, Environ. Sci. Technol., 38, 4085-4090, 2004.

Bauer, S. E., Bausch, A., Nazarenko, L., Tsigaridis, K., Xu, B. Q., Edwards, R., Bisiaux, M., and McConnell, J.: Historical and future black carbon deposition on the three ice caps: Ice core measurements and model simulations from 1850 to 2100, J. Geophys. Res.-Atmos., 118, 7948-7961, 2013.

Bohleber, P., Wagenbach, D., Schöner, W., and Böhm, R.: To what extent do water isotope records from low accumulation Alpine ice cores reproduce instrumental temperature series?, Tellus B, $65,17,2013$. 
Bohleber, P., Erhardt, T., Spaulding, N., Hoffmann, H., Fischer, H., and Mayewski, P.: Temperature and mineral dust variability recorded in two low-accumulation Alpine ice cores over the last millennium, Clim. Past, 14, 21-37, https://doi.org/10.5194/cp14-21-2018, 2018.

Böhm, R., Jones, P. D., Hiebl, J., Frank, D., Brunetti, M., and Maugeri, M.: The early instrumental warm-bias: a solution for long central European temperature series 1760-2007, Clim. Change, 101, 41-67, 2010.

Bond, T. C., Streets, D. G., Yarber, K. F., Nelson, S. M., Woo, J. H., and Klimont, Z.: A technology-based global inventory of black and organic carbon emissions from combustion, J. Geophys. Res.-Atmos., 109, D14203, https://doi.org/10.1029/2003JD003697, 2004.

Bond, T. C. and Sun, H. L.: Can reducing black carbon emissions counteract global warming?, Environ. Sci. Technol., 39, 59215926, 2005.

Bond, T. C., Bhardwaj, E., Dong, R., Jogani, R., Jung, S. K., Roden, C., Streets, D. G., and Trautmann, N. M.: Historical emissions of black and organic carbon aerosol from energy-related combustion, 1850-2000, Global Biogeochem. Cy., 21, GB2018, https://doi.org/10.1029/2006GB002840, 2007.

Bond, T. C., Doherty, S. J., Fahey, D. W., Forster, P. M., Berntsen, T., DeAngelo, B. J., Flanner, M. G., Ghan, S., Karcher, B., Koch, D., Kinne, S., Kondo, Y., Quinn, P. K., Sarofim, M. C., Schultz, M. G., Schulz, M., Venkataraman, C., Zhang, H., Zhang, S., Bellouin, N., Guttikunda, S. K., Hopke, P. K., Jacobson, M. Z., Kaiser, J. W., Klimont, Z., Lohmann, U., Schwarz, J. P., Shindell, D., Storelvmo, T., Warren, S. G., and Zender, C. S.: Bounding the role of black carbon in the climate system: A scientific assessment, J. Geophys. Res.-Atmos., 118, 5380-5552, 2013.

Brohan, P., Allan, R., Freeman, E., Wheeler, D., Wilkinson, C., and Williamson, F.: Constraining the temperature history of the past millennium using early instrumental observations, Clim. Past, 8, 1551-1563, https://doi.org/10.5194/cp-8-1551-2012, 2012.

Büntgen, U., Tegel, W., Nicolussi, K., McCormick, M., Frank, D., Trouet, V., Kaplan, J. O., Herzig, F., Heussner, K. U., Wanner, H., Luterbacher, J., and Esper, J.: 2500 Years of European Climate Variability and Human Susceptibility, Science, 331, 578582, 2011.

Cao, F., Zhang, Y. L., Szidat, S., Zapf, A., Wacker, L., and Schwikowski, M.: Microgram-Level Radiocarbon Determination of Carbonaceous Particles in Firn and Ice Samples: Pretreatment and Oc/Ec Separation, Radiocarbon, 55, 383-390, 2013.

Charlson, R. J., Schwartz, S. E., Hales, J. M., Cess, R. D., Coakley, J. A., Hansen, J. E., and Hofmann, D. J.: Climate Forcing by Anthropogenic Aerosols, Science, 255, 423-430, 1992.

Chellman, N., McConnell, J. R., Arienzo, M., Pederson, G. T., Aarons, S. M., and Csank, A.: Reassessment of the Upper Fremont Glacier Ice-Core Chronologies by Synchronizing of IceCore-Water Isotopes to a Nearby Tree-Ring Chronology, Environ. Sci. Technol., 51, 4230-4238, 2017.

Currie, L. A., Benner, B. A., Kessler, J. D., Klinedinst, D. B., Klouda, G. A., Marolf, J. V., Slater, J. F., Wise, S. A., Cachier, H., Cary, R., Chow, J. C., Watson, J., Druffel, E. R. M., Masiello, C. A., Eglinton, T. I., Pearson, A., Reddy, C. M., Gustafsson, O., Quinn, J. G., Hartmann, P. C., Hedges, J. I., Prentice, K. M., Kirchstetter, T. W., Novakov, T., Puxbaum, H., and Schmid, H.: A critical evaluation of interlaboratory data on total, elemental, and isotopic carbon in the carbonaceous particle reference material, NIST SRM 1649a, J. Res. Natl. Inst. Stan., 107, 279-298, 2002.

Döscher, A., Gäggeler, H. W., Schotterer, U., and Schwikowski, M.: A 130 years deposition record of sulfate, nitrate and chloride from a high-alpine glacier, Water Air Soil Poll., 85, 603-609, 1995.

Döscher, A., Gäggeler, H. W., Schotterer, U., and Schwikowski, M.: A historical record of ammonium concentrations from a glacier in the Alps, Geophys. Res. Lett., 23, 2741-2744, 1996.

Dubovik, O., Holben, B., Eck, T. F., Smirnov, A., Kaufman, Y. J., King, M. D., Tanre, D., and Slutsker, I.: Variability of absorption and optical properties of key aerosol types observed in worldwide locations, J. Atmos. Sci., 59, 590-608, 2002.

Engardt, M., Simpson, D., Schwikowski, M., and Granat, L.: Deposition of sulphur and nitrogen in Europe 1900-2050, Model calculations and comparison to historical observations, Tellus B, 69, 1328945, https://doi.org/10.1080/16000889.2017.1328945, 2017.

Eyring, V., Bony, S., Meehl, G. A., Senior, C. A., Stevens, B., Stouffer, R. J., and Taylor, K. E.: Overview of the Coupled Model Intercomparison Project Phase 6 (CMIP6) experimental design and organization, Geosci. Model Dev., 9, 1937-1958, https://doi.org/10.5194/gmd-9-1937-2016, 2016.

Fagerli, H., Legrand, M., Preunkert, S., Vestreng, V., Simpson, D., and Cerqueira, M.: Modeling historical long-term trends of sulfate, ammonium, and elemental carbon over Europe: A comparison with ice core records in the Alps, J. Geophys. Res.-Atmos., 112, D23S13, https://doi.org/10.1029/2006JD008044, 2007.

Fischer, H., Schüpbach, S., Gfeller, G., Bigler, M., Rothlisberger, R., Erhardt, T., Stocker, T. F., Mulvaney, R., and Wolff, E.: Millennial changes in North American wildfire and soil activity over the last glacial cycle, Nat. Geosci., 8, 723-727, 2015.

Flanner, M. G.: Arctic climate sensitivity to local black carbon, J. Geophys. Res.-Atmos., 118, 1840-1851, 2013.

Flanner, M. G. and Zender, C. S.: Snowpack radiative heating: Influence on Tibetan Plateau climate, Geophys. Res. Lett., 32, L06501, https://doi.org/10.1029/2004GL022076, 2005.

Flanner, M. G., Zender, C. S., Randerson, J. T., and Rasch, P. J.: Present-day climate forcing and response from black carbon in snow, J. Geophys. Res.-Atmos., 112, D11202, https://doi.org/10.1029/2006JD008003, 2007.

Flanner, M. G., Zender, C. S., Hess, P. G., Mahowald, N. M., Painter, T. H., Ramanathan, V., and Rasch, P. J.: Springtime warming and reduced snow cover from carbonaceous particles, Atmos. Chem. Phys., 9, 2481-2497, https://doi.org/10.5194/acp9-2481-2009, 2009.

Frank, D., Büntgen, U., Böhm, R., Maugeri, M., and Esper, J.: Warmer early instrumental measurements versus colder reconstructed temperatures: shooting at a moving target, Quaternary Sci. Rev., 26, 3298-3310, 2007.

Gabbi, J., Huss, M., Bauder, A., Cao, F., and Schwikowski, M.: The impact of Saharan dust and black carbon on albedo and long-term mass balance of an Alpine glacier, The Cryosphere, 9, 13851400, https://doi.org/10.5194/tc-9-1385-2015, 2015.

Gabrieli, J. and Barbante, C.: The Alps in the age of the Anthropocene: the impact of human activities on the cryosphere recorded in the Colle Gnifetti glacier, Rend Lincei-Sci. Fis., 25, 71-83, 2014. 
Gabrieli, J., Vallelonga, P., Cozzi, G., Gabrielli, P., Gambaro, A., Sigl, M., Decet, F., Schwikowski, M., Gaggeler, H., Boutron, C., Cescon, P., and Barbante, C.: Post 17th-Century Changes of European PAH Emissions Recorded in High-Altitude Alpine Snow and Ice, Environ. Sci. Technol., 44, 3260-3266, 2010.

Gabrieli, J., Cozzi, G., Vallelonga, P., Schwikowski, M., Sigl, M., Eickenberg, J., Wacker, L., Boutron, C., Gaggeler, H., Cescon, P., and Barbante, C.: Contamination of Alpine snow and ice at Colle Gnifetti, Swiss/Italian Alps, from nuclear weapons tests, Atmos. Environ., 45, 587-593, 2011.

Gentner, D. R., Isaacman, G., Worton, D. R., Chan, A. W. H., Dallmann, T. R., Davis, L., Liu, S., Day, D. A., Russell, L. M., Wilson, K. R., Weber, R., Guha, A., Harley, R. A., and Goldstein, A. H.: Elucidating secondary organic aerosol from diesel and gasoline vehicles through detailed characterization of organic carbon emissions, P. Natl. Acad. Sci. USA, 109, 18318-18323, 2012.

Gentner, D. R., Jathar, S. H., Gordon, T. D., Bahreini, R., Day, D. A., El Haddad, I., Hayes, P. L., Pieber, S. M., Platt, S. M., de Gouw, J., Goldstein, A. H., Harley, R. A., Jimenez, J. L., Prevot, A. S. H., and Robinson, A. L.: Review of Urban Secondary Organic Aerosol Formation from Gasoline and Diesel Motor Vehicle Emissions, Environ. Sci. Technol., 51, 1074-1093, 2017.

Goosse, H., Barriat, P.-Y., Dalaiden, Q., Klein, F., Marzeion, B., Maussion, F., Pelucchi, P., and Vlug, A.: Testing the consistency between changes in simulated climate and Alpine glacier length over the past millennium, Clim. Past, 14, 1119-1133, https://doi.org/10.5194/cp-14-1119-2018, 2018.

Häberli, W., Schotterer, U., Wagenbach, D., Häberlischwitter, H., and Bortenschlager, S.: Accumulation Characteristics on a Cold, High-Alpine Firn Saddle from a Snow-Pit Study on ColleGnifetti, Monte-Rosa, Swiss Alps, J. Glaciol., 29, 260-271, 1983.

Hansen, J. and Nazarenko, L.: Soot climate forcing via snow and ice albedos, P. Natl. Acad. Sci. USA, 101, 423-428, 2004.

Hansen, J., Sato, M., Ruedy, R., Kharecha, P., Lacis, A., Miller, R., Nazarenko, L., Lo, K., Schmidt, G. A., Russell, G., Aleinov, I., Bauer, S., Baum, E., Cairns, B., Canuto, V., Chandler, M., Cheng, Y., Cohen, A., Del Genio, A., Faluvegi, G., Fleming, E., Friend, A., Hall, T., Jackman, C., Jonas, J., Kelley, M., Kiang, N. Y., Koch, D., Labow, G., Lerner, J., Menon, S., Novakov, T., Oinas, V., Perlwitz, J., Perlwitz, J., Rind, D., Romanou, A., Schmunk, R., Shindell, D., Stone, P., Sun, S., Streets, D., Tausnev, N., Thres-her, D., Unger, N., Yao, M., and Zhang, S.: Climate simulations for 1880-2003 with GISS modelE, Clim. Dynam., 29, 661-696, 2007.

Hawkins, E. and Sutton, R.: Time of emergence of climate signals, Geophys. Res. Lett., 39, L01702, https://doi.org/10.1029/2011GL050087, 2012.

Haywood, J. and Boucher, O.: Estimates of the direct and indirect radiative forcing due to tropospheric aerosols: A review, Rev. Geophys., 38, 513-543, 2000.

Hirdman, D., Burkhart, J. F., Sodemann, H., Eckhardt, S., Jefferson, A., Quinn, P. K., Sharma, S., Ström, J., and Stohl, A.: Long-term trends of black carbon and sulphate aerosol in the Arctic: changes in atmospheric transport and source region emissions, Atmos. Chem. Phys., 10, 9351-9368, https://doi.org/10.5194/acp-109351-2010, 2010.

Huss, M., Hock, R., Bauder, A., and Funk, M.: 100-year mass changes in the Swiss Alps linked to the Atlantic
Multidecadal Oscillation, Geophys. Res. Lett., 37, L10501, https://doi.org/10.1029/2010GL042616, 2010.

Imhof, P., Nesje, A., and Nussbaumer, S. U.: Climate and glacier fluctuations at Jostedalsbreen and Folgefonna, southwestern Norway and in the western Alps from the "Little Ice Age" until the present: The influence of the North Atlantic Oscillation, Holocene, 22, 235-247, 2012.

Jenk, T. M., Szidat, S., Schwikowski, M., Gäggeler, H. W., Brütsch, S., Wacker, L., Synal, H.-A., and Saurer, M.: Radiocarbon analysis in an Alpine ice core: record of anthropogenic and biogenic contributions to carbonaceous aerosols in the past (1650-1940), Atmos. Chem. Phys., 6, 5381-5390, https://doi.org/10.5194/acp6-5381-2006, 2006.

Jenk, T. M., Szidat, S., Bolius, D., Sigl, M., Gaggeler, H. W., Wacker, L., Ruff, M., Barbante, C., Boutron, C. F., and Schwikowski, M.: A novel radiocarbon dating technique applied to an ice core from the Alps indicating late Pleistocene ages, J. Geophys. Res.-Atmos., 114, D14305, https://doi.org/10.1029/2009JD011860, 2009.

Jungclaus, J. H., Bard, E., Baroni, M., Braconnot, P., Cao, J., Chini, L. P., Egorova, T., Evans, M., González-Rouco, J. F., Goosse, H., Hurtt, G. C., Joos, F., Kaplan, J. O., Khodri, M., Klein Goldewijk, K., Krivova, N., LeGrande, A. N., Lorenz, S. J., Luterbacher, J., Man, W., Maycock, A. C., Meinshausen, M., Moberg, A., Muscheler, R., Nehrbass-Ahles, C., Otto-Bliesner, B. I., Phipps, S. J., Pongratz, J., Rozanov, E., Schmidt, G. A., Schmidt, H., Schmutz, W., Schurer, A., Shapiro, A. I., Sigl, M., Smerdon, J. E., Solanki, S. K., Timmreck, C., Toohey, M., Usoskin, I. G., Wagner, S., Wu, C.-J., Yeo, K. L., Zanchettin, D., Zhang, Q., and Zorita, E.: The PMIP4 contribution to CMIP6 - Part 3: The last millennium, scientific objective, and experimental design for the PMIP4 past1000 simulations, Geosci. Model Dev., 10, 40054033, https://doi.org/10.5194/gmd-10-4005-2017, 2017.

Junker, C. and Liousse, C.: A global emission inventory of carbonaceous aerosol from historic records of fossil fuel and biofuel consumption for the period 1860-1997, Atmos. Chem. Phys., 8, 1195-1207, https://doi.org/10.5194/acp-8-1195-2008, 2008.

Kaspari, S. D., Schwikowski, M., Gysel, M., Flanner, M. G., Kang, S., Hou, S., and Mayewski, P. A.: Recent increase in black carbon concentrations from a Mt. Everest ice core spanning 1860-2000 AD, Geophys. Res. Lett., 38, L04703, https://doi.org/10.1029/2010GL046096, 2011.

Keegan, K. M., Albert, M. R., McConnell, J. R., and Baker, I.: Climate change and forest fires synergistically drive widespread melt events of the Greenland Ice Sheet, P. Natl. Acad. Sci. USA, 111, 7964-7967, 2014.

Kirchgeorg, T., Dreyer, A., Gabrieli, J., Kehrwald, N., Sigl, M., Schwikowski, M., Boutron, C., Gambaro, A., Barbante, C., and Ebinghaus, R.: Temporal variations of perfluoroalkyl substances and polybrominated diphenyl ethers in alpine snow, Environ. Pollut., 178, 367-374, 2013.

Koch, D., Bauer, S. E., Del Genio, A., Faluvegi, G., McConnell, J. R., Menon, S., Miller, R. L., Rind, D., Ruedy, R., Schmidt, G. A., and Shindell, D.: Coupled Aerosol-Chemistry-Climate Twentieth-Century Transient Model Investigation: Trends in Short-Lived Species and Climate Responses, J. Climate, 24, 2693-2714, 2011.

Konrad, H., Bohleber, P., Wagenbach, D., Vincent, C., and Eisen, O.: Determining the age distribution of Colle Gnifetti, Monte 
Rosa, Swiss Alps, by combining ice cores, ground-penetrating radar and a simple flow model, J. Glaciol., 59, 179-189, 2013.

Lack, D. A., Moosmuller, H., McMeeking, G. R., Chakrabarty, R. K., and Baumgardner, D.: Characterizing elemental, equivalent black, and refractory black carbon aerosol particles: a review of techniques, their limitations and uncertainties, Anal. Bioanal. Chem., 406, 99-122, 2014.

Lamarque, J.-F., Bond, T. C., Eyring, V., Granier, C., Heil, A., Klimont, Z., Lee, D., Liousse, C., Mieville, A., Owen, B., Schultz, M. G., Shindell, D., Smith, S. J., Stehfest, E., Van Aardenne, J., Cooper, O. R., Kainuma, M., Mahowald, N., McConnell, J. R., Naik, V., Riahi, K., and van Vuuren, D. P.: Historical (1850-2000) gridded anthropogenic and biomass burning emissions of reactive gases and aerosols: methodology and application, Atmos. Chem. Phys., 10, 7017-7039, https://doi.org/10.5194/acp-10-7017-2010, 2010.

Lamarque, J.-F., Dentener, F., McConnell, J., Ro, C.-U., Shaw, M., Vet, R., Bergmann, D., Cameron-Smith, P., Dalsoren, S., Doherty, R., Faluvegi, G., Ghan, S. J., Josse, B., Lee, Y. H., MacKenzie, I. A., Plummer, D., Shindell, D. T., Skeie, R. B., Stevenson, D. S., Strode, S., Zeng, G., Curran, M., Dahl-Jensen, D., Das, S., Fritzsche, D., and Nolan, M.: Multi-model mean nitrogen and sulfur deposition from the Atmospheric Chemistry and Climate Model Intercomparison Project (ACCMIP): evaluation of historical and projected future changes, Atmos. Chem. Phys., 13, 7997-8018, https://doi.org/10.5194/acp-137997-2013, 2013.

Larsen, D. J., Miller, G. H., and Geirsdottir, A.: Asynchronous Little Ice Age glacier fluctuations in Iceland and European Alps linked to shifts in subpolar North Atlantic circulation, Earth Planet Sc. Lett., 380, 52-59, 2013.

Lau, W. K. M., Kim, M. K., Kim, K. M., and Lee, W. S.: Enhanced surface warming and accelerated snow melt in the Himalayas and Tibetan Plateau induced by absorbing aerosols, Environ. Res. Lett., 5, 025204, https://doi.org/10.1088/1748-9326/5/2/025204, 2010.

Lavanchy, V. M. H., Gaggeler, H. W., Schotterer, U., Schwikowski, M., and Baltensperger, U.: Historical record of carbonaceous particle concentrations from a European high-alpine glacier (Colle Gnifetti, Switzerland), J. Geophys. Res.-Atmos., 104, $21227-$ 21236, 1999.

Le Roy, M., Nicolussi, K., Deline, P., Astrade, L., Edouard, J. L., Miramont, C., and Arnaud, F.: Calendar-dated glacier variations in the western European Alps during the Neoglacial: the Mer de Glace record, Mont Blanc massif, Quaternary Sci. Rev., 108, 122, 2015.

Lee, W. S., Bhawar, R. L., Kim, M. K., and Sang, J.: Study of aerosol effect on accelerated snow melting over the Tibetan Plateau during boreal spring, Atmos. Environ., 75, 113-122, 2013.

Lee, Y. H., Lamarque, J.-F., Flanner, M. G., Jiao, C., Shindell, D. T., Berntsen, T., Bisiaux, M. M., Cao, J., Collins, W. J., Curran, M., Edwards, R., Faluvegi, G., Ghan, S., Horowitz, L. W., McConnell, J. R., Ming, J., Myhre, G., Nagashima, T., Naik, V., Rumbold, S. T., Skeie, R. B., Sudo, K., Takemura, T., Thevenon, F., Xu, B., and Yoon, J.-H.: Evaluation of preindustrial to present-day black carbon and its albedo forcing from Atmospheric Chemistry and Climate Model Intercompar- ison Project (ACCMIP), Atmos. Chem. Phys., 13, 2607-2634, https://doi.org/10.5194/acp-13-2607-2013, 2013.

Lim, S., Faïn, X., Zanatta, M., Cozic, J., Jaffrezo, J.-L., Ginot, P., and Laj, P.: Refractory black carbon mass concentrations in snow and ice: method evaluation and inter-comparison with elemental carbon measurement, Atmos. Meas. Tech., 7, 3307-3324, https://doi.org/10.5194/amt-7-3307-2014, 2014.

Linke, C., Möhler, O., Veres, A., Mohácsi, Á., Bozóki, Z., Szabó, G., and Schnaiter, M.: Optical properties and mineralogical composition of different Saharan mineral dust samples: a laboratory study, Atmos. Chem. Phys., 6, 3315-3323, https://doi.org/10.5194/acp-6-3315-2006, 2006.

Liu, J. F., Fan, S. M., Horowitz, L. W., and Levy, H.: Evaluation of factors controlling long-range transport of black carbon to the Arctic, J. Geophys. Res.-Atmos., 116, D04307, https://doi.org/10.1029/2010JD015145, 2011.

Lohmann, U. and Feichter, J.: Global indirect aerosol effects: a review, Atmos. Chem. Phys., 5, 715-737, https://doi.org/10.5194/acp-5-715-2005, 2005.

Luo, B.: Stratospheric aerosol data for use in CMIP6 models, available at: ftp://iacftp.ethz.ch/pub_read/luo/CMIP6/, last access: 21 November 2016.

Lugauer, M., Baltensperger, U., Furger, M., Gaggeler, H. W., Jost, D. T., Schwikowski, M., and Wanner, H.: Aerosol transport to the high Alpine sites Jungfraujoch (3454 masl) and Colle Gnifetti (4452 m asl), Tellus B, 50, 76-92, 1998.

Luterbacher, J., Werner, J. P., Smerdon, J. E., Fernandez-Donado, L., Gonzalez-Rouco, F. J., Barriopedro, D., Ljungqvist, F. C., Büntgen, U., Zorita, E., Wagner, S., Esper, J., McCarroll, D., Toreti, A., Frank, D., Jungclaus, J. H., Barriendos, M., Bertolin, C., Bothe, O., Brazdil, R., Camuffo, D., Dobrovolny, P., Gagen, M., Garica-Bustamante, E., Ge, Q., Gomez-Navarro, J. J., Guiot, J., Hao, Z., Hegerl, G. C., Holmgren, K., Klimenko, V. V., Martin-Chivelet, J., Pfister, C., Roberts, N., Schindler, A., Schurer, A., Solomina, O., von Gunten, L., Wahl, E., Wanner, H., Wetter, O., Xoplaki, E., Yuan, N., Zanchettin, D., Zhang, H., and Zerefos, C.: European summer temperatures since Roman times, Environ. Res. Lett., 11, 024001, https://doi.org/10.1088/17489326/11/2/024001, 2016.

Lüthi, M. P.: Little Ice Age climate reconstruction from ensemble reanalysis of Alpine glacier fluctuations, The Cryosphere, 8 , 639-650, https://doi.org/10.5194/tc-8-639-2014, 2014.

McConnell, J. R. and Edwards, R.: Coal burning leaves toxic heavy metal legacy in the Arctic, P. Natl. Acad. Sci. USA, 105, 1214012144, 2008.

McConnell, J. R., Edwards, R., Kok, G. L., Flanner, M. G., Zender, C. S., Saltzman, E. S., Banta, J. R., Pasteris, D. R., Carter, M. M., and Kahl, J. D. W.: 20th-century industrial black carbon emissions altered arctic climate forcing, Science, 317, 1381-1384, 2007.

McConnell, J. R., Wilson, A. I., Stohl, A., Arienzo, M. M., Chellman, N. J., Eckhardt, S., Thompson, E. M., Pollard, A. M., and Steffensen, J. P.: Lead pollution recorded in Greenland ice indicates European emissions tracked plagues, wars, and imperial expansion during antiquity, P. Natl. Acad. Sci. USA, 115, 57265731, https://doi.org/10.1073/pnas.1721818115, 2018.

Mernild, S. H., Lipscomb, W. H., Bahr, D. B., Radic, V., and Zemp, M.: Global glacier changes: a revised assessment of commit- 
ted mass losses and sampling uncertainties, The Cryosphere, 7, 1565-1577, https://doi.org/10.5194/tc-7-1565-2013, 2013.

Mernild, S. H., Hanna, E., McConnell, J. R., Sigl, M., Beckerman, A. P., Yde, J. C., Cappelen, J., Malmros, J. K., and Steffen, K.: Greenland precipitation trends in a long-term instrumental climate context (1890-2012): evaluation of coastal and ice core records, Int. J. Climatol., 35, 303-320, 2015.

Moulin, C. and Chiapello, I.: Impact of human-induced desertification on the intensification of Sahel dust emission and export over the last decades, Geophys. Res. Lett., 33, L18808, https://doi.org/10.1029/2006GL025923, 2006.

Nussbaumer, S. U. and Zumbühl, H. J.: The Little Ice Age history of the Glacier des Bossons (Mont Blanc massif, France): a new high-resolution glacier length curve based on historical documents, Clim. Change, 111, 301-334, 2012.

Nyeki, S., Kalberer, M., Colbeck, I., De Wekker, S., Furger, M., Gaggeler, H. W., Kossmann, M., Lugauer, M., Steyn, D., Weingartner, E., Wirth, M., and Baltensperger, U.: Convective boundary layer evolution to $4 \mathrm{~km}$ asl over high-alpine terrain: Airborne lidar observations in the Alps, Geophys. Res. Lett., 27, 689-692, 2000.

Oerlemans, J.: Extracting a climate signal from 169 glacier records, Science, 308, 675-677, 2005.

Oeschger, H.: First results from Alpine core drilling projects, Z. Gletscherkunde Glazialgeologie, 13, 193-208, 1977.

Painter, T. H., Flanner, M. G., Kaser, G., Marzeion, B., VanCuren, R. A., and Abdalati, W.: End of the Little Ice Age in the Alps forced by industrial black carbon, P. Natl. Acad. Sci. USA, 110, 15216-15221, 2013.

Penner, J. E., Chuang, C. C., and Grant, K.: Climate forcing by carbonaceous and sulfate aerosols, Clim. Dynam., 14, 839-851, 1998.

Petzold, A., Ogren, J. A., Fiebig, M., Laj, P., Li, S.-M., Baltensperger, U., Holzer-Popp, T., Kinne, S., Pappalardo, G., Sugimoto, N., Wehrli, C., Wiedensohler, A., and Zhang, X.-Y.: Recommendations for reporting "black carbon" measurements, Atmos. Chem. Phys., 13, 8365-8379, https://doi.org/10.5194/acp13-8365-2013, 2013.

Platt, S. M., El Haddad, I., Pieber, S. M., Zardini, A. A., SuarezBertoa, R., Clairotte, M., Daellenbach, K. R., Huang, R. J., Slowik, J. G., Hellebust, S., Temime-Roussel, B., Marchand, N., de Gouw, J., Jimenez, J. L., Hayes, P. L., Robinson, A. L., Baltensperger, U., Astorga, C., and Prevot, A. S. H.: Gasoline cars produce more carbonaceous particulate matter than modern filter-equipped diesel cars, Sci. Rep.-UK, 7, 4926, https://doi.org/10.1038/s41598-017-03714-9, 2017.

Polashenski, C. M., Dibb, J. E., Flanner, M. G., Chen, J. Y., Courville, Z. R., Lai, A. M., Schauer, J. J., Shafer, M. M., and Bergin, M.: Neither dust nor black carbon causing apparent albedo decline in Greenland's dry snow zone: Implications for MODIS C5 surface reflectance, Geophys. Res. Lett., 42, 93199327, 2015.

Quinn, P. K., Bates, T. S., Baum, E., Doubleday, N., Fiore, A. M., Flanner, M., Fridlind, A., Garrett, T. J., Koch, D., Menon, S., Shindell, D., Stohl, A., and Warren, S. G.: Shortlived pollutants in the Arctic: their climate impact and possible mitigation strategies, Atmos. Chem. Phys., 8, 1723-1735, https://doi.org/10.5194/acp-8-1723-2008, 2008.
Raible, C. C., Bronnimann, S., Auchmann, R., Brohan, P., Frolicher, T. L., Graf, H. F., Jones, P., Luterbacher, J., Muthers, S., Neukom, R., Robock, A., Self, S., Sudrajat, A., Timmreck, C., and Wegmann, M.: Tambora 1815 as a test case for high impact volcanic eruptions: Earth system effects, WIRES Clim. Change, 7, 569589, 2016.

Revell, L. E., Stenke, A., Luo, B., Kremser, S., Rozanov, E., Sukhodolov, T., and Peter, T.: Impacts of Mt Pinatubo volcanic aerosol on the tropical stratosphere in chemistryclimate model simulations using CCMI and CMIP6 stratospheric aerosol data, Atmos. Chem. Phys., 17, 13139-13150, https://doi.org/10.5194/acp-17-13139-2017, 2017.

Ruggieri, E.: A Bayesian approach to detecting change points in climatic records, Int. J. Climatol., 33, 520-5-28, 2013.

Schwarz, J. P., Gao, R. S., Fahey, D. W., Thomson, D. S., Watts, L. A., Wilson, J. C., Reeves, J. M., Darbeheshti, M., Baumgardner, D. G., Kok, G. L., Chung, S. H., Schulz, M., Hendricks, J., Lauer, A., Karcher, B., Slowik, J. G., Rosenlof, K. H., Thompson, T. L., Langford, A. O., Loewenstein, M., and Aikin, K. C.: Single-particle measurements of midlatitude black carbon and light-scattering aerosols from the boundary layer to the lower stratosphere, J. Geophys. Res.-Atmos., 111, D16207, https://doi.org/10.1029/2006JD007076, 2006.

Schwikowski, M., Döscher, A., Gäggeler, H. W., and Schotterer, U.: Anthropogenic versus natural sources of atmospheric sulphate from an Alpine ice core, Tellus B, 51, 938-951, 1999a.

Schwikowski, M., Brütsch, S., Gäggeler, H. W., and U. Schotterer, U.:, A high-resolution air chemistry record from an Alpine ice core: Fiescherhorn glacier, Swiss Alps, J. Geophys. Res., 104, 13709-13719, 1999b.

Schwikowski, M., Barbante, C., Doering, T., Gaeggeler, H. W., Boutron, C., Schotterer, U., Tobler, L., Van De Velde, K. V., Ferrari, C., Cozzi, G., Rosman, K., and Cescon, P.: Post-17thcentury changes of European lead emissions recorded in highaltitude alpine snow and ice, Environ. Sci. Technol., 38, 957964, 2004.

Shindell, D. T., Lamarque, J.-F., Schulz, M., Flanner, M., Jiao, C., Chin, M., Young, P. J., Lee, Y. H., Rotstayn, L., Mahowald, N., Milly, G., Faluvegi, G., Balkanski, Y., Collins, W. J., Conley, A. J., Dalsoren, S., Easter, R., Ghan, S., Horowitz, L., Liu, X., Myhre, G., Nagashima, T., Naik, V., Rumbold, S. T., Skeie, R., Sudo, K., Szopa, S., Takemura, T., Voulgarakis, A., Yoon, J.-H., and Lo, F.: Radiative forcing in the ACCMIP historical and future climate simulations, Atmos. Chem. Phys., 13, 2939-2974, https://doi.org/10.5194/acp-13-2939-2013, 2013.

Sigl, M., Jenk, T. M., Kellerhals, T., Szidat, S., Gäggeler, H. W., Wacker, L., Synal, H. A., Boutron, C., Barbante, C., Gabrieli, J., and Schwikowski, M.: Towards radiocarbon dating of ice cores, J. Glaciol., 55, 985-996, 2009.

Sigl, M., McConnell, J. R., Layman, L., Maselli, O., McGwire, K., Pasteris, D., Dahl-Jensen, D., Steffensen, J. P., Vinther, B., Edwards, R., Mulvaney, R., and Kipfstuhl, S.: A new bipolar ice core record of volcanism from WAIS Divide and NEEM and implications for climate forcing of the last 2000 years, J. Geophys. Res.-Atmos., 118, 1151-1169, 2013.

Sigl, M., Winstrup, M., McConnell, J. R., Welten, K. C., Plunkett, G., Ludlow, F., Buntgen, U., Caffee, M., Chellman, N., Dahl-Jensen, D., Fischer, H., Kipfstuhl, S., Kostick, C., Maselli, O. J., Mekhaldi, F., Mulvaney, R., Muscheler, R., Pasteris, D. 
R., Pilcher, J. R., Salzer, M., Schüpbach, S., Steffensen, J. P., Vinther, B. M., and Woodruff, T. E.: Timing and climate forcing of volcanic eruptions for the past 2500 years, Nature, 523, 543-549, 2015

Sigl, M., Abram, N. J., Gabrieli, J., Jenk, T. M., Osmont, D., and Schwikowski, M.: Record of black carbon (rBC), bismuth, lead and others from 1741 to 2015 AD from Colle Gnifetti ice cores GC15 and GC03B (Swiss/Italian Alps), PANGAEA, https://doi.org/10.1594/PANGAEA.894787, 2018.

Solomina, O. N., Bradley, R. S., Jomelli, V., Geirsdottir, A., Kaufman, D. S., Koch, J., Mckay, N. P., Masiokas, M., Miller, G., Nesje, A., Nicolussi, K., Owen, L. A., Putnam, A. E., Wanner, H., Wiles, G., and Yang, B.: Glacier fluctuations during the past 2000 years, Quaternary Sci. Rev., 149, 61-90, 2016.

Steiner, D., Pauling, A., Nussbaumer, S. U., Nesje, A., Luterbacher, J., Wanner, H., and Zumbuhl, H. J.: Sensitivity of European glaciers to precipitation and temperature - two case studies, Clim. Change, 90, 413-441, 2008.

Stohl, A.: Characteristics of atmospheric transport into the Arctic troposphere, J. Geophys. Res.-Atmos., 111, D11306, https://doi.org/10.1029/2005JD006888, 2006.

Sun, J., Zhi, G., Hitzenberger, R., Chen, Y., Tian, C., Zhang, Y., Feng, Y., Cheng, M., Zhang, Y., Cai, J., Chen, F., Qiu, Y., Jiang, Z., Li, J., Zhang, G., and Mo, Y.: Emission factors and light absorption properties of brown carbon from household coal combustion in China, Atmos. Chem. Phys., 17, 4769-4780, https://doi.org/10.5194/acp-17-4769-2017, 2017.

Swingedouw, D., Mignot, J., Ortega, P., Khodri, M., Menegoz, M., Cassou, C., and Hanquiez, V.: Impact of explosive volcanic eruptions on the main climate variability modes, Global Planet. Change, 150, 24-45, 2017.

Thevenon, F., Anselmetti, F. S., Bernasconi, S. M., and Schwikowski, M.: Mineral dust and elemental black carbon records from an Alpine ice core (Colle Gnifetti glacier) over the last millennium, J. Geophys. Res.-Atmos., 114, D17102, https://doi.org/10.1029/2008JD011490, 2009.

Toohey, M. and Sigl, M.: Volcanic stratospheric sulfur injections and aerosol optical depth from 500 BCE to 1900 CE, Earth Syst. Sci. Data, 9, 809-831, https://doi.org/10.5194/essd-9-809-2017, 2017.
Uglietti, C., Zapf, A., Jenk, T. M., Sigl, M., Szidat, S., Salazar, G., and Schwikowski, M.: Radiocarbon dating of glacier ice: overview, optimisation, validation and potential, The Cryosphere, 10, 3091-3105, https://doi.org/10.5194/tc-10-30912016, 2016.

Usoskin, I. G.: A history of solar activity over millenia, Living Rev Sol. Phys., 14, 3, https://doi.org/10.1007/s41116-017-00069, 2013

Vincent, C., Le Meur, E., Six, D., and Funk, M.: Solving the paradox of the end of the Little Ice Age in the Alps, Geophys. Res. Lett., 32, L09706, https://doi.org/10.1029/2005GL022552, 2005.

Wagenbach, D. and Geis, K.: The Mineral Dust Record in a HighAltitude Alpine Glacier (Colle-Gnifetti, Swiss Alps), Nato Adv. Sci. I C-Mat., 282, 543-564, 1989.

Wagenbach, D., Preunkert, S., Schafer, J., Jung, W., and Tomadin, L.: Northward transport of Saharan dust recorded in a deep Alpine ice core, Envir. Sci. Tech Lib, 11, 291-300, 1996.

Wagenbach, D., Bohleber, P., and Preunkert, S.: Cold, Alpine Ice Bodies Revisited: What May We Learn from Their Impurity and Isotope Content?, Geogr. Ann. A, 94, 245-263, 2012.

Wegmann, M., Bronnimann, S., Bhend, J., Franke, J., Folini, D., Wild, M., and Luterbacher, J.: Volcanic Influence on European Summer Precipitation through Monsoons: Possible Cause for "Years without Summer", J. Climate, 27, 3683-3691, 2014.

Wendl, I. A., Menking, J. A., Färber, R., Gysel, M., Kaspari, S. D., Laborde, M. J. G., and Schwikowski, M.: Optimized method for black carbon analysis in ice and snow using the Single Particle Soot Photometer, Atmos. Meas. Tech., 7, 2667-2681, https://doi.org/10.5194/amt-7-2667-2014, 2014.

Zekollari, H., Furst, J. J., and Huybrechts, P.: Modelling the evolution of Vadret da Morteratsch, Switzerland, since the Little Ice Age and into the future, J. Glaciol., 60, 1155-1168, 2014.

Zemp, M., Haeberli, W., Hoelzle, M., and Paul, F.: Alpine glaciers to disappear within decades?, Geophys. Res. Lett., 33, L13504, https://doi.org/10.1029/2006GL026319, 2006.

Zumbühl, H. J., Steiner, D., and Nussbaumer, S. U.: 19th century glacier representations and fluctuations in the central and western European Alps: An interdisciplinary approach, Global Planet. Change, 60, 42-57, 2008. 